\title{
CERAMIC TECHNOLOGY. HOW TO CHARACTERISE CERAMIC GLAZES
}

\author{
Trinitat Pradell ${ }^{1, *}$ and Judit Molera ${ }^{2}$ \\ ${ }^{1}$ Physics Department and BRCMSE, Universitat Politècnica de Catalunya, Barcelona, Spain \\ Email: Trinitat.Pradell@upc.edu; ORCID: 0000-0002-8720-5492 \\ ${ }^{2}$ MECAMAT, Engineering Department, Faculty of Sciences and Technology, Universitat de Vic - \\ Universitat Central de Catalunya, Barcelona, Spain \\ Email: Judit.Molera@uvic.cat; ORCID: 0000-0003-3116-0456
}

\begin{abstract}
Glazes add value to ceramic; improve its appearance (colour and shine) and make it waterproof. Through the choice of colours and designs, glazes made ceramics fashionable, even luxurious, and therefore, an object of trade. Each region and ruling dynasty developed its own style or trademark which makes them particularly suitable for dating purposes. Therefore, the study and analysis of glazes offers direct information about the acquisition of technical skills (technology), trade of specific materials (inter-regional links), migrations and the introduction/adoption of new trends.
\end{abstract}

A ceramic glaze is a thin glassy layer fused to the surface of a ceramic body through firing. The interaction between the glaze and the ceramic body results in the interdiffusion of elements between both. A glaze consists mainly of an amorphous phase, but also includes bubbles, cracks and crystalline phases (undissolved compounds and crystals formed during the firing). Finally, the glazes were also decorated, a large variety of materials and methods of applying the decorations were used.

In this chapter we present a summary of the technical characteristics of glazes (composition, microstructures and technical requirements), their discovery and use throughout history, and decorative techniques. The methodology and analytical techniques to obtain the information are also discussed.

*Corresponding author: Trinitat Pradell. Email: Trinitat.Pradell@upc.edu

Keywords: alkali glazes, lead glazes, tin glazes, lime glazes, technology, decorations

\section{Declarations:}

Funding - The project received long time financial support from MINECO (Spain), latest grant MAT2016-77753-R and Generalitat de Catalunya, latest grant 2017 SGR 0042.

Conflicts of interest/Competing interests - The authors have no conflicts of interest to declare. Code availability - Not applicable

Availability of data and material - Data sharing is not applicable to this review article as no new data were created or analyzed in this study.

Authors' contributions - Not applicable 


\section{PREMISE}

This paper contributes to the Topical Issue (TI) "Ceramics: Research questions and answers" aimed at guiding researchers in the study of archaeological ceramics from excavation to study and preservation in museum collections.

Each contribution has a tutorial approach covering one of the main issues pertaining to the study of ceramics: research questions and sampling criteria (Gliozzo 2020a); the chemical (Hein and Kilikoglou 2020) and mineralogical-petrographic (Montana 2020) investigation of raw materials; the technological character and suitability of raw materials (Gualtieri 2020); the processing (Eramo 2020) and modelling (Thér 2020) of clays; surface finishing (Ionescu and Hoeck 2020) and ceramic firing (Gliozzo 2020b); the investigation of different coatings such as black glass-ceramic (Aloupi-Siotis 2020), terra sigillata (Sciau et al. 2020) and glazes (this paper); the isotopic study of particular types of products such as Chinese ceramics (Henderson et al. 2020); the identification of post-burial transformations (Maritan 2020); the dating of ceramics (Galli et al. 2020); and the restoration and musealisation of ceramics (de Lapérouse 2020). This Topical Issue concludes with a tutorial on statistical data processing (Papageorgiou 2020). 


\section{WHY ANALYSE GLAZES?}

Glazes are responsible for the appearance (colour and brilliancy) of the ceramics but they also have a function; they make the ceramics waterproof enabling them to contain liquids and food (kitchen and table ware). Glazes added value to the ceramic objects and through the choice of colours and designs, made them fashionable, in some cases even making them a luxury product, and therefore, an object of trade. With the consequent increase in demand, they were copied, sold at a lower price and, at length, became of common use. Additionally, each region and ruling dynasty developed its own style or trademark of glazed ceramics, which together with their abundance on archaeological sites compared to other materials, makes them particularly suitable for dating purposes.

Studies of glazes provide information about their chemical composition, their microstructure, and firing technologies, as well as the type and style of decoration. The characteristics of the glazes are directly related to the latest technical and scientific advances, and to fashion. Moreover, analysis of glazes offers indirect information about the acquisition of technical skills, trade of specific materials that cannot be found locally, the connection or the absence of connection between regions, and the introduction and adoption of new trends. Both the learning of new technical skills and the availability of the raw materials are necessary for the successful development of a product. However, the adoption of a new glazed ware with the "appearance" of an imported glazed ware is not necessarily associated with the use of the same method of production or materials. The adoption and copy of new designs and colours is often not accurate enough to make them undistinguishable from the original. Consequently, the information obtained from analysing glazes 1) provides a detailed characterisation of the glaze itself, 2) allows for a technological reconstruction and 3) helps to distinguish local productions from imports, especially when combined with the morphological and stylistical classification (i.e. typology).

The existence of any surviving documentation such as literary sources is very important as they provide direct information of the raw materials used and methods followed in the glazed ware production. However, the reconstruction which can be achieved on that basis is partial and does not extend to all the ceramic types and periods. In addition, in many cases, the descriptions are difficult to translate into modern concepts. For example, the materials are often called by names that may have various meanings or are related to local sources unknown today. It is also not uncommon that the texts were not actually written by the potters themselves but by other people who were not directly related to the production itself, and who had to interpret what they were told, with more or less success. 
Although it is assumed, following an anthropological and ethnological approach, that the methods of production (materials used, processing of the materials, firing protocols) of glazed ceramics were similar to those used in contemporary traditional ceramic workshops, the analysis of the materials unearthed from some earlier historical workshops has demonstrated that this assumption is not necessarily correct (Salinas 2019a).

Consequently, the study and analysis of glazed wares and any material related to the production of glazes is essential, not only for those interested in the technology, but also for those studying inter-regional connections, migrations of people, establishment of trade patterns, and trends in diffusion. Finally, the information obtained is also very important in order to design adequate conservation processes and strategies (De Lapérouse 2020, in this issue).

\section{WHAT IS THE DIFFERENCE BETWEEN GLASS and GLAZE?}

\subsection{Main features of non-crystalline solids: Glass}

Glasses are non-crystalline (or amorphous) solids formed from a melt by cooling to solid state (glass transition temperature) without crystallization. In the past, glasses were defined as supercooled liquids as a result of their disordered atomic structure lacking the long-range order that is characteristic of crystalline solids (Vogel 1992, Shelby 2005). Glasses, therefore, result from a kinetic process, are thermodynamically unstable, structurally disordered and chemically complex.

Historical glasses are "silicate glasses" based on silicon dioxide $\left(\mathrm{SiO}_{2}\right)$, referred to also as silica. An ideal silicate glass can be described as a random three-dimensional network of $\left(\mathrm{SiO}_{4}\right)^{4-}$ tetrahedral units, which act as the building blocks of the glass structure. The main characteristics of silicate glass are transparency, chemical and thermal resistance, hardness and fragility. Silicate glasses are hard to produce due to their high melting temperature $\left(1723^{\circ} \mathrm{C}\right.$ for pure silica). Also, they start to become rigid and therefore, become difficult to work below a high temperature $\left(\sim 1185^{\circ} \mathrm{C}\right)$. Therefore, other compounds, called fluxes, are added to silica to lower the melting temperature and reduce the viscosity of the melt. The most common fluxes are alkali oxides, sodium and potassium oxides $\left(\mathrm{Na}_{2} \mathrm{O}, \mathrm{K}_{2} \mathrm{O}\right)$, and lead oxide $(\mathrm{PbO})$. Fluxes react strongly with silica, producing homogeneous melts at a lower temperature, for instance, a congruent melt between silica and sodium silicate $\left(\mathrm{Na}_{2} \mathrm{O} \cdot \mathrm{SiO}_{2}\right)$ takes place at $793^{\circ} \mathrm{C}$ (eutectic composition 74 $\mathrm{wt} \% \mathrm{SiO}_{2}$ ), and that of lead oxide and silica at $717^{\circ} \mathrm{C}$ (eutectic composition, $70 \mathrm{wt} \% \mathrm{PbO}$ ). However, the addition of large amounts of fluxes results in a serious degradation of many properties, in particular chemical stability (i.e. sodium silicate glasses). This is normally 
counteracted by adding other elements, which act as stabilisers or property modifiers, which can substitute silicon in the glass structure providing the necessary electronic charge balance (Shelby 2005); among them we can highlight alkaline earth $(\mathrm{CaO})$ and transition metal oxides and most importantly alumina $\left(\mathrm{Al}_{2} \mathrm{O}_{3}\right)$. In fact, most of these elements may also act as weak fluxes for silica, for instance $\mathrm{CaO}$ acts as a very efficient flux at higher temperatures, and a homogeneous melt of $\mathrm{CaO}$ and silica $\left(\mathrm{CaO}-\mathrm{SiO}_{2}\right)$ is obtained at $1473^{\circ} \mathrm{C}$ (eutectic composition, $\left.63 \mathrm{wt} \% \mathrm{SiO}_{2}\right)$. Other compounds are those added in very small amounts $(<1 \%)$ to remove bubbles (fining agents), such as arsenic and antimony oxides, salt and some sulphates. Finally, further elements are added to impart colour to the glass (colourants), such as iron, copper, manganese or cobalt which will be discussed in detail in section 2.2.

The production of a melt is a complex process involving; the reactivity of solid compounds, formation of a first lower temperature melt, dissolution of solid compounds in the melt and release of gases. The production and properties of the glass obtained depend not only on the firing temperature and composition of the glass, but also on the whole thermal process followed, in particular, the cooling process, and on the nature of the compounds added. For instance, sodium oxide can be added as sodium carbonate $\left(\mathrm{Na}_{2} \mathrm{CO}_{3}\right)$, sulphate $\left(\mathrm{Na}_{2} \mathrm{SO}_{4}\right)$, chloride (salt, $\mathrm{NaCl}$ ), or as feldspar (sodium aluminosilicate, albite, $\mathrm{NaAlSi}_{3} \mathrm{O}_{8}$ ); mainly affecting the firing protocol but also leaving traces of the associated elements. Once a glass is obtained it can be softened again by heating (softening point, viscosity $10^{6.5} \mathrm{~Pa} \cdot \mathrm{s}$ ) and can be blown (flow point, viscosity $10^{4} \mathrm{~Pa} \cdot \mathrm{s}$ ), and also at a higher temperature blown into a mould (working point, viscosity $\left.10^{3} \mathrm{~Pa} \cdot s\right)$.

\subsection{Glazes}

A ceramic glaze is a thin glassy layer fused to the surface of a ceramic body through firing. The main difference between glaze and glass is that the glaze has a large surface to volume ratio, and that it interacts with the ceramic body and the atmosphere. Glass is essentially a closed system (the chemical composition does not change significantly during firing) while a glaze is an open system (the chemical composition changes during firing mainly due to the interaction with the ceramic and the volatilisation of some of the compounds). The interaction between the glaze and the ceramic body results in the interdiffusion of elements from the glaze into the body and from the body into the glaze. Consequently, glazes are not homogeneous, showing chemical composition gradients across the glaze thickness due to diffusion (Molera 2001). The interaction region (called interface) could be neat or filled with crystals formed by the reaction between the paste and the glaze (Figure 1) depending on temperature, single or double firing, and the composition of the paste and the glaze (Molera 1993, Tite 1998, Molera 2001, Pradell 2010). 
Moreover, bubbles, raw material particles in the process of dissolution, and other reaction compounds developed during the glaze production, are also often present in the glaze (Figure 1).

The main features characterising a glaze can be distinguished between microstructures -such as bubbles and cracks- and compounds. Among the former, microstructures can be primary (during firing/cooling) or secondary (post burial alteration), while the latter can be either amorphous or crystalline.

- Amorphous phase (Figure 1A): corresponds to the heterogeneous melt formed during firing which incorporates some elements from the ceramic body. The composition of the melt depends on the firing temperature and the fact that some particles remain undissolved.

- Undissolved compounds (Figure 1B): They are the partially reacted original glaze compounds which normally show rounded forms with dissolving surfaces. Large sand particles are common and can be responsible for the opacity of glazes. Around quartz grains, characteristic crack lines are often observed due to alpha to beta phase transition at $573^{\circ} \mathrm{C}$.

- Crystalline compounds (Figure 1D): Crystalline compounds form from elements which become insoluble mainly during the cooling. Slow cooling favours the growth of the crystallites. Some compounds are more prone to crystallise than others (Figure 1A). Crystalline compounds can also be formed due to alteration during burial.

- Bubbles (Figure 1B): They are inherent to the glazes and have different origins. At the beginning of glaze melting, bubbles form from the gases released by the decomposition of organic compounds and carbonates $\left(\mathrm{CO}_{2}, \mathrm{CO}\right)$, sulphates $\left(\mathrm{SO}_{2}\right)$ and the dehydroxylation of the clay minerals $\left(\mathrm{OH}^{-}\right)$, or from air and moisture trapped inside the glaze. Bubbles are beneficial due to their mixing and stirring action which aids in the homogenization of the melt. These bubbles can be fully removed depending on the thickness of the glaze, the viscosity of the melt, the surface tension of the bubbles and the temperature and length of the firing. At higher temperatures new bubbles are formed by the boiling process (gases which change their chemistry becoming insoluble, or those which decrease their solubility at higher temperatures), but distinguishing between the two types of bubbles is difficult.

- Crazing (Figure 1C): Small hairline cracks on the glazed surfaces due to the stresses developed between the ceramic and the glaze during cooling. Crazing happens when the shrinkage of the glaze is more accentuated than that of the ceramic to which it is rigidly attached. A craze pattern can develop immediately after removal from the kiln or years later. Cracks facilitate the corrosion of the glazes. 
As occurs with glass, the colours of the glazes are obtained by the presence/addition of transition metals, fired under oxidising or reducing conditions. The colour given to the glazes is due to the nature (iron, copper, manganese, cobalt), valence $\left(\mathrm{Fe}^{2+}, \mathrm{Fe}^{3+}, \mathrm{Cu}^{2+}, \mathrm{Cu}^{+}, \mathrm{Cu}^{\mathrm{o}}, \mathrm{Co}^{2+}\right.$, $\mathrm{Mn}^{3+}$ ), coordination number (four, five, six) and geometrical arrangement (tetrahedral, octahedral,..) of the neighbouring atoms (Weyl 1951). The colour is caused by the absorption of light at specific light wavelengths by the metal ions (Figure 2). Iron is the most important colourant as it is the most abundant impurity present in rocks and may produce many colours. $\mathrm{Fe}^{2+}$ has a high absorption in the infrared with a large tail extending into the red and yellow, and consequently, imparts a blue colour to the glaze. $\mathrm{Fe}^{3+}$ has some lower absorption bands in the ultraviolet and blue, imparting a yellow tinge to the glaze (Figure 2). Both are normally present in the glaze, the $\mathrm{Fe}^{2+} / \mathrm{Fe}^{3+}$ ratio being determined by the atmosphere and firing temperature; the higher the temperature the higher the ratio. The complete elimination of iron from the glaze is often impossible as it can be incorporated into the structure of most clay minerals; the selection of naturally low iron materials is the main way to avoid the colouring effect of iron. However, if its colouring effect is desired, a reducing firing will provide a blue colour while an oxidising firing will result in a yellow/brown colour. For equivalent amounts of iron, the colouring effect of $\mathrm{Fe}^{2+}$ is far more important than that of $\mathrm{Fe}^{3+}$, therefore, it was common to introduce small amounts of other elements such as manganese, arsenic or antimony which involve a redox reaction in which iron is oxidised.

As with iron, copper is also capable of imparting a wide range of colours to the glaze. Under oxidising conditions, $\mathrm{Cu}^{2+}$ and $\mathrm{Cu}^{+}$are both present, and the high broad absorption of $\mathrm{Cu}^{2+}$ in the red with a large tail extending to the yellow (Figure 2), taken together with variations in the coordination and nature of the neighbouring atoms, produces a range of colours from turquoise to green. In contrast, firing under reducing conditions may result in the reduction of some of the copper to metallic copper, $\mathrm{Cu}^{\circ}$, which forms nanometric crystallites and provides a red to darkred colour to the glaze.

$\mathrm{Mn}^{3+}$ gives a purplish colour to the glaze, black in large concentrations. Nevertheless, the position of the absorption band varies strongly with the composition of the glass, (470 $\mathrm{nm}$ for a soda-lime and $520 \mathrm{~nm}$ for a potash-lime glass) shifting the colour from more reddish to more bluish (Figure 2). Moreover, trivalent manganese is often in coexistence with $\mathrm{Mn}^{2+}$ which imparts a faint yellow or brown colour.

Finally, cobalt is present as $\mathrm{Co}^{2+}$, but gives a blue colour if linked to four oxygens, tetrahedral coordination $\left(\mathrm{CoO}_{4}\right)$, and a pink colour if linked to six oxygens, octahedral coordination $\left(\mathrm{CoO}_{6}\right)$ (Figure 2). The change from tetrahedral to octahedral coordination due to the loss of potassium 
is known to be responsible for the faint blue colour of smalt, a cobalt blue potash glass, used as a pigment in paintings.

The main difference between glass and glaze colour is that the interaction of the glaze with the ceramic body is a source of introducing colouring elements into the glaze. Moreover, the colour of the ceramic bodies (greyish, reddish, creamy, etc.) may show through the transparent glaze and hinder the aesthetic purpose of the glaze. Therefore, although transparency is typically sought for glasses, this is not necessarily the case for glazes. Consequently, it is not uncommon to benefit from the presence of undissolved particles (Figure 3A), crystallites formed during the firing (Figure 3C, 3D) and bubbles (Figure 3B) which increase the opacity of the glaze.

Finally, corrosion microstructures formed due to the use or burial of the glazed object, are also often present. Corrosion involves the leaching of glaze components and incorporation of elements from the environment and, finally, the precipitation of new compounds (Figure 4), and this must be taken into account when analysing the glazes. Glaze corrosion is one part of the post-depositional transformations which occur in ceramics (Maritan 2020, in this issue).

The investigation of glazes implies the study and characterisation of multiple features. Nevertheless, first of all, we have to distinguish between low temperature and high temperature glazes. Low temperature glazes are fired at temperatures between $900^{\circ} \mathrm{C}$ and $1050^{\circ} \mathrm{C}$ while high temperature glazes are those obtained at temperatures above $1100^{\circ} \mathrm{C}$. Why is this distinction so important? Because different firing temperatures require different glaze composition and hence ceramic composition. For instance, high lead glazes should not be fired at temperatures above $1050^{\circ} \mathrm{C}$ to avoid an excess of lead volatilization, while calcium fluxed glazes must be fired at temperatures above $1200^{\circ} \mathrm{C}$ in order to melt. The most common fluxes used to produce low temperature glazes $\left(\sim 900-1050^{\circ} \mathrm{C}\right)$ are alkali oxides $\left(\mathrm{Na}_{2} \mathrm{O}, \mathrm{K}_{2} \mathrm{O}\right)$, lead oxide $(\mathrm{PbO})$ and boron oxide $\left(\mathrm{B}_{2} \mathrm{O}_{3}\right)$ while the fluxes used to produce high temperature glazes $\left(\sim 1100-1300^{\circ} \mathrm{C}\right)$ are alkaline earth oxides $(\mathrm{CaO}$ and $\mathrm{BaO})$ and $\mathrm{ZnO}$.

\section{LOW TEMPERATURE GLAZES}

\subsection{ALKALI GLAZES.}

\subsubsection{Definition}

Alkali glazes are those obtained using alkali oxides $\left(\mathrm{Na}_{2} \mathrm{O}, \mathrm{K}_{2} \mathrm{O}\right)$ as fluxing agents, adding small amounts of $\mathrm{CaO}$ as a stabilizer and firing at a low temperature, typically $\sim 900-1050^{\circ} \mathrm{C}$. The fluxes used were obtained from natural alkali salts (hydroxides, carbonates, sulphates) among 
which natron ${ }^{1}$ is historically the most important, obtained also from ashes of salt-tolerant plants commonly referred to as barrilla $^{2}$, and from organic-mineral deposits, such as saltpetre ${ }^{3}$.

\subsubsection{The historical development and geographical distribution}

The earliest alkali glazed objects, known as faience ${ }^{4}$, were produced in Egypt and the Near East during the $4^{\text {th }}$ millennium BC (Early Dynastic period), from a mixture of sand, sodium rich fluxing compounds (natron) and water, which was compacted, left to dry and fired. During the drying the salts migrated together with the water to the surface where a glaze was formed after firing. Variations of this method of production include the burial of the object in a flux rich glazing powder inside a vessel, and the application of the glazing slurry on the surface of the object before firing (Vandiver 1982 and 1983; Kingery 1986; Tite 1983).

The first glazed clay plant-ash based, alkali-lime type ceramic appeared in Mesopotamia in the middle of the $2^{\text {nd }}$ millennium BC. The production of these ceramics spread across the Near East, from Syria to Iran, inspiring a long-standing tradition, through the Parthian and Sassanian periods (Kleinmann 1986, McCarthy 1996, Hill 2004, Pace 2008), and into the Islamic age.

In China, high temperature glazes predominated. However, potash turquoise glazes over earthenware ${ }^{5}$ were also produced since the $12^{\text {th }}$ century (Wood 1999), followed by colourful decorated alkali glazes of the lead-potash type which were produced from the mid $14^{\text {th }}$ century (Cizhou style) and later, they were used in the Chinese cloisonné (Fahua ware) in $15^{\text {th }}-16^{\text {th }}$ centuries.

\subsubsection{Production technology}

Glazes are, generally speaking, obtained applying a thin layer $(1$ to $3 \mathrm{~cm}$ ) of the raw powder compounds mixed with water onto the ceramic surface. However, as many alkali raw compounds are water soluble, such as sodium carbonate and also, although to a lesser extent,

1 Natron is a naturally occurring mix of sodium carbonate decahydrate $\left(\mathrm{Na}_{2} \mathrm{CO}_{3} \cdot 10 \mathrm{H}_{2} \mathrm{O}\right)$ and sodium bicarbonate $\left(\mathrm{NaHCO}_{3}\right)$ along with small quantities of sodium chloride and sodium sulphate found in saline lake beds in arid environments.

2 Barrilla is a mixture of mainly sodium carbonate, variable amounts of potassium carbonate and some impurities. It was obtained boiling the water used to wash the ashes of burned halophyte dried plants found in coastal salt marshes and seashores.

3 Saltpetre, potassium nitrate $\left(\mathrm{KNO}_{3}\right)$ can be found in caves as crystallizing efflorescence of organic decomposition or bat guano, or artificially made of nitrogen from urine rich soil with mineral potassium.

4 Faience or Egyptian faience was used to design the Egyptian glazed objects made of crushed quartz; the name was taken from the city of Faenza in Ravenna (Italy) known for its quality production of decorated white opaque glazed wares which showed a similar appearance to the Egyptian objects. It is obviously a misnomer but well accepted in Ancient Egypt and Near East contexts.

5 Earthenware is the English name for ceramics and tiles made of clay and fired at temperatures below $1100^{\circ} \mathrm{C}$. 
calcium carbonate, they can migrate into the clay body or crystallise over the glaze surface during drying. This produces a scum forming on the glaze during firing, and thus the glaze appears powdery with patches of glaze mixed with regions showing undissolved glaze components (Paynter 2001). Moreover, sodium may also be volatilised during firing. Consequently, in order to obtain a good homogeneous glaze, the alkali compounds are fired with silica, that is, fritted, before preparing the glaze suspension. Another advantage of using a frit is that it already contains a glassy compound, which when fired above the softening temperature (typically between $100{ }^{\circ} \mathrm{C}$ and $200^{\circ} \mathrm{C}$ lower than the maturing temperatures) will produce a liquid melt capable of reacting with the ceramic body, fusing the glaze to the ceramic and shortening the firing protocol.

Soda-lime glazes are characterised by a low maturing temperature, transparency and a high thermal expansion coefficient $\left(9-10 \cdot 10^{-6} \mathrm{~K}^{-1}\right)$. The high thermal expansion coefficient of the glaze compared to that of the ceramic body generates cracks in the glazes (ie crazing) during the cooling phase, while a very low thermal expansion coefficient may cause peeling of the glaze (Tite 1998). Typical thermal expansion coefficients for ceramics are $3-5 \cdot 10^{-6} \mathrm{~K}^{-1}$ for noncalcareous types, $5-7 \cdot 10^{-6} \mathrm{~K}^{-1}$ for calcareous ceramics and $7-9 \cdot 10^{-6} \mathrm{~K}^{-1}$ for stonepaste ${ }^{6}$ bodies (Mason and Tite 1994). Soda-lime glazes therefore show extensive cracking on non-calcareous ceramics, but this is less of a problem with calcareous clay, and no problem for stonepastes, made from a mixture of sand and frit. The production of stonepastes with soda-lime glazes started quite late in either Fatimid Egypt or Syria $\left(11^{\text {th }}-12^{\text {th }}\right.$ century AD). In contrast, transparent high lead glazes with a thermal expansion coefficient of $5-7 \cdot 10^{-6} \mathrm{~K}^{-1}$ are compatible with clay ceramics (Tite 1998), and this has been highlighted as a possible reason for the use of high lead glazes and mixed lead-alkali glazes in the early Islamic productions. Lead glazes will be discussed in section 3.2.

Similarly, the potash glazes used in China also have a low maturing temperature but they do not cause crazing on earthenware, and potassium is not volatilised during firing. They could be applied directly without fritting as saltpetre has low water solubility. Moreover, the addition of flocculants (vinegar, calcium chloride among others) is also useful in increasing the viscosity of the suspension and in facilitating their application (Wood 1999). Consequently, they were also easy to make and thus, in due course, mixed potash-lead glazes were also applied over stoneware and porcelain.

6 Islamic stonepaste also called fritware is an artificial mixture of sand and a glass frit plus some clay discovered by the Islamic potters in the $12^{\text {th }}$ century in either Egypt or Syria. The ceramic bodies obtained are very white, suitable for decoration. It should not be confused with Chinese stoneware which refers to the natural rocks used to produce Chinese ceramic bodies. 
Although the best known early alkali glazes were turquoise coloured by the addition of copper, they also appeared in green (copper), purple (manganese) and yellow (iron), (Figure 2) (Paynter 2001, Hill 2004, Wood 1999).

\subsection{LEAD GLAZES}

\subsubsection{Definition}

Lead glazes are those obtained using lead oxide $(\mathrm{PbO})$ as a fluxing agent and fired at a low temperature, typically $\sim 900-1050^{\circ} \mathrm{C}$. Typically, lead oxide can either be applied directly over the ceramic from where it takes the $\mathrm{SiO}_{2}$, or mixed with sand. Lead oxide does not dissolve in water and is vaporised at temperatures above $1100^{\circ} \mathrm{C}$, and therefore it does not need fritting.

\subsubsection{The historical development and geographical distribution}

The first lead glazes, were produced in the Roman Empire $\left(1^{\text {st }} \mathrm{BC}\right.$ to $\left.4^{\text {th }} \mathrm{AD}\right)$, either by applying $\mathrm{PbO}$ directly over the raw non-calcareous ceramic bodies or by applying lead plus sand (mainly quartz), with a composition close to the eutectic point (about $70 \% \mathrm{PbO}+30 \% \mathrm{SiO}_{2}$ ) over calcareous bodies, the addition of sand probably being due to the insufficient quartz available in the calcareous clays (Walton 2004). From the $4^{\text {th }}$ century AD onwards in European late antiquity, the Byzantine Empire, the Islamic lands (Walton 2004, Waksman 2008) and also in the Han and Tang dynasties in China (Wood 1999), the mixture of lead oxide and sand seems to prevail, irrespective of the type of body. Subsequently in the Islamic world, as discussed in the context of tin opacification (section 4), high lead glazes developed into lead-alkali glazes.

Nevertheless, recent archaeological evidence shows that the method of production of lead glazes was quite complex in the western Mediterranean Islamic region. According to the latest research, an Islamic glazed ceramic workshop found at Pechina, al-Andalus, dated in the $9^{\text {th }}$ century AD, has given new information about the methods of production (Salinas 2019a). Lead oxide was obtained in the workshop roasting galena ${ }^{7}$ in a small kiln. Then, a mixture of the lead oxide and silica was submitted to a complex fritting process which involved several stages at the end of which a high lead glass was obtained, ground and applied over the biscuit-fired ceramics which were then fired to a temperature high enough to soften the glaze. Considering that this is not necessary at all for the production of a lead glaze and that lead glazed wares were discontinued in the Iberian Peninsula in late Antiquity, either the potters came from other Islamic regions or they developed the lead glaze technology on their own. This complex process of production did not continue; there is direct evidence that in the Hispano-Moresque

7 Galena, lead sulphide $(\mathrm{PbS})$ is a lead ore. 
workshops from the $13^{\text {th }}$ century onwards, lead glazes were made from a mixture of lead oxide and sand, and not fritted. Lead glazes were applied both over low calcareous clays (5-7\% $\mathrm{CaO})$ for culinary uses and also over non-calcareous clays for all kind of cooking pots.

Finally, other lead compounds were also used to obtain a lead glaze. In particular galena mixed with sand was used for the production of large plain lead glazed water containers and other culinary objects in Catalonia from the $18^{\text {th }}$ century onwards (Di Febo 2018).

\subsubsection{Technology of production}

As a consequence of the interaction when lead oxide is directly applied over a ceramic body, the source of silica is the ceramic body itself, and therefore, the glaze literally "digests" the ceramic. Lead oxide reacts with the quartz of the ceramic at about $717^{\circ} \mathrm{C}$ and a first melt is formed. The other components of the ceramic are later dissolved into this first liquid (Walton 2004). The amount of ceramic digested is directly related to the firing temperature. Moreover, the presence of chemical diffusion profiles appear due to the difference in composition between the melting glaze and the ceramic body, and this depends on the glaze and ceramic composition. This digestion/diffusion process also happens in glazing mixtures containing quartz, or quartz and clay (Molera 2001). In fact, comparing the $\mathrm{SiO}_{2}$ and $\mathrm{Al}_{2} \mathrm{O}_{3}$ content of the ceramic and of the glaze, calculated removing the lead oxide and colourants and renormalizing, it is relatively easy to deduce whether a mixture of lead oxide and quartz, rather than only lead oxide, was used (Walton 2004). Lead oxide alone was used if the $\mathrm{SiO}_{2}$ and $\mathrm{Al}_{2} \mathrm{O}_{3}$ contents were the same, while a mixture of lead oxide and sand was used if the $\mathrm{SiO}_{2}$ content of the glaze was higher and the $\mathrm{Al}_{2} \mathrm{O}_{3}$ content lower than those of the ceramic (Walton 2004).

Moreover, due to the interaction between the glaze and ceramic body, the precipitation of other crystalline compounds usually happens at the interface between the ceramic and the glaze. The nature and composition of the crystallites depend on the firing temperature, and the composition of both the ceramic body and the glaze (Figure 1C) (Molera 2001, Pradell 2010). For lead glazes, lead-potassium feldspars ${ }^{8}$ of variable composition (Molera 1993) are formed. Both, lead and alkali glazes on calcareous ceramics give rise to the formation of calcium silicates (wollastonite ${ }^{9}$ ), and over a calcium and magnesium rich ceramic to calcium magnesium silicates (pyroxenes ${ }^{10}$ ) (Figure 1D). In fact, the chemical composition of the glaze-ceramic interface and

8 Feldspars are tectosilicates found in igneous and some metamorphic rock; groups are of the alkali type with typical composition $(\mathrm{Na}, \mathrm{K}) \mathrm{AlSi}_{3} \mathrm{O}_{8}$, plagioclase with typical composition $\mathrm{NaAlSi}_{3} \mathrm{O}_{8}$ $\mathrm{CaAl}_{2} \mathrm{Si}_{2} \mathrm{O}_{8}$. At the interface with a lead glaze, lead potassium feldspars of typical formula $(\mathrm{K}, \mathrm{Pb}) \mathrm{AlSi}_{3} \mathrm{O}_{8}$ are also formed.

9 Wollastonite is a calcium inosilicate, $\mathrm{CaSiO}_{3}$.

10 Pyroxenes are inosilicates found in igneous and metamorphic rocks, those formed in glazes have typical formulae $(\mathrm{Ca}, \mathrm{Mg}, \mathrm{Fe})_{2} \mathrm{Si}_{2} \mathrm{O}_{6}$. 
the precipitation of crystalline compounds, modify the thermal expansion coefficient and consequently affect the crazing of the glaze; magnesium rich ceramic bodies develop less crazing than calcium rich ceramic bodies (Paynter 2001).

It has been suggested that the thickness of the reaction layer could be directly related to way the glaze was applied over a raw or fired ceramic substrate (Tite 1998) and to the firing temperature (Walton 2004). However, a more extensive analysis of the data shows that other factors such as the thickness of the glaze and firing protocol (time/temperature), but also the composition of the ceramic, may result in the formation of a thicker or thinner interaction layer.

The colours of lead glazes are also the result of the presence of iron (yellow for $\mathrm{Fe}^{3+}$ and green for $\mathrm{Fe}^{2+}$ ), copper (green for $\mathrm{Cu}^{2+} / \mathrm{Cu}^{+}$), manganese (purplish, mainly due to $\mathrm{Mn}^{3+}$, brown mainly due to $\mathrm{Mn}^{2+}$ ) and cobalt (dark blue, $\mathrm{CoO}_{4}$ ) (Figure 2).

\subsection{OPACITY}

The formation of crystalline compounds resulting from the interaction, dissolution and diffusion of elements from the ceramic body into the glaze may modify the transparency and colour of the glazes. Also, the colour of the ceramic will affect the final colour of a transparent glaze.

The presence of iron in the ceramic body can significantly disturb the appearance of the glaze. The iron oxides present in the ceramic body give a red or black colour when fired in oxidising or reducing conditions, respectively, and oxidised/reduced iron $\left(\mathrm{Fe}^{3+} / \mathrm{Fe}^{2+}\right)$ dissolved from the ceramic into the glaze imparts a yellow/green colour to the glaze, respectively (Molera 1997). In order to ensure that the presence of iron does not interfere in the final appearance of the glaze, a number of different strategies were adopted. First, calcareous ceramic bodies fired under slightly reducing conditions are known to develop a buff coloured surface due to the incorporation of iron into the calcium silicates and aluminosilicates (gehlenite ${ }^{11}$, pyroxens and plagioclase) formed in the ceramic, leaving less iron to form iron oxide responsible for the red and black colour (Molera 1998). Second, the reactivity among the ceramic body compounds can be enhanced by adding some fluxing agent such as salt (sodium chloride) to the ceramic surface. The presence of salt will enhance the formation of a silica melt where calcium silicates and aluminosilicates that incorporate iron will more easily be produced. In both cases, the ceramic body has to be fired prior to the application of the glaze, and consequently, two firings, one for the ceramic (biscuit) and another for the glaze, are necessary.

11 Gehlenite, is a sorosilicate, with formulae $\mathrm{Ca}_{2} \mathrm{Al}\left(\mathrm{AlSiO}_{7}\right)$, formed by the decomposition calcium carbonate and reaction with the clay at a temperature between $750^{\circ} \mathrm{C}$ and $850^{\circ} \mathrm{C}$. 
A third strategy to minimise the interference of the ceramic body in the final appearance of the glaze is the application of a slip ${ }^{12}$ on top of the ceramic surface and prior to the application of the glaze. The use of white clay mixed with quartz creates a white opaque layer that hides the colour of the ceramic body. Then the glaze is applied over the slip. Nevertheless, as slip painting is also a decorative technique, it will be discussed in section 7 .

As debated in the literature (Paynter 2001), a fourth strategy to conceal the colour of the underlying body is to reduce the transparency of the glaze adding particles to the glaze which will scatter light. This was achieved by adding coarse silt or sand to the glaze with particle sizes which would not dissolve during the firing, increasing the concentration of calcium and/or magnesium oxides in the glaze which would give rise to the precipitation of crystallites such as calcium and/or magnesium silicates (wollastonite and pyroxenes), or alternatively, underfiring the glaze which would produce large bubbles and un-melted raw particles. Generally speaking, large bubbles and undissolved particles (quartz), produce a partially opaque glaze, while small particles and the newly formed crystalline compounds at the glaze-ceramic interface such as calcium and/or magnesium silicates or aluminosilicates (feldspars), which scatter light more efficiently, increase the opacity of the glaze (Figure 1D, Figure 3).

In fact, the use of tin oxide (cassiterite ${ }^{13}$ ) as an opacifier lead to the development of the socalled tin glazes and marked the beginning of a new era.

\section{TIN GLAZES}

\subsection{Definition}

As we have seen before, transparency is not necessarily a desirable quality for the glazes as the colour of the underlying ceramic body interferes with the colour of the glaze or of the decorative motifs. Consequently, fully opaque glazes able to hide the ceramic body were sought, in particular for low temperature ceramics. Opacity is increased if small crystallites $(\sim 1 \mu \mathrm{m})$ with a high refraction index and neat crystalline surfaces, preferably crystallized during the firing, are present in the glaze (Molera 1999, Vendrell 2000) (Figure 3C). Among the suitable crystalline materials, tin and antimony oxides were used in the past, while in modern times $\left(19^{\text {th }}\right.$ century) titanium oxide substituted tin oxide.

Since the beginning of glass production, first calcium antimonate $\left(\mathrm{CaSb}_{2} \mathrm{O}_{6}\right)$ and later cassiterite were used to produce white opaque glasses, while lead-antimonate $\left((\mathrm{Sb}, \mathrm{Sn}, \mathrm{Fe})_{2} \mathrm{~Pb}_{2} \mathrm{O}_{7}\right)$ and subsequently, lead-tin oxide $\left(\left(\mathrm{Pb}, \mathrm{Si}_{2} \mathrm{Sn}_{2} \mathrm{O}_{6}\right)\right.$ were used to produce yellow opaque glasses. These compounds are highly soluble in the alkali-lime glass, and consequently, to avoid their

12 A slip is a slurry made of clay, quartz and sometimes a colourant or pigment particles suspended in water applied over the ceramic surface to give a finishing and/or a colour.

13 Cassiterite, tin IV oxide of formula $\mathrm{SnO}_{2}$. 
dissolution, they were not added directly to the glass batch during its melting, but were added as a pigment, anime or corpus $^{14}$ to the reheated glass. However, this procedure is not possible in the production of a glaze. On the contrary, tin oxide is highly insoluble in the lead glaze and therefore, it can be directly included in the lead glaze batch to obtain small crystallites of tin oxide. This discovery gave rise to the development of white opaque tin glazes (containing cassiterite particles) and of a new era.

\subsection{The historical development and geographical distribution of tin glazes}

The incorporation of tin into a lead glaze resulted in ceramics much closer in appearance to Chinese stoneware and porcelain; and for a long time, it has generally been accepted that the first tin glazes were produced in the Abbasid caliphate (Iraq $9^{\text {th }}$ AD) (Figure 1C) by Islamic potters in order to imitate Chinese celadons ${ }^{15}$ (Northedge 2001).

However, the earliest use of tin was for the production of a yellow opaque glaze containing lead-tin oxide particles and decorated with green and brown designs (Watson 2004, Tite 2015, Matin 2018) in the so-called Coptic glazed ware produced in Egypt and in yellow glazed family produced in the Levant in the $8^{\text {th }}$ century -early $9^{\text {th }}$ century AD (Rodziewitcz 1983 , Whitcomb 1989). White tin opaque glazes are found together with yellow opaque glazes in the Levant but are of a very different composition from those found in Iraq. The white glazes were of the high lead-alkali type ( $40-50 \% \mathrm{PbO}, 5-6 \% \mathrm{SnO}_{2}$ and $<10 \%$ alkali and alkali-earth), while in Iraq they were of the alkali-low lead type $\left(\sim 1-15 \% \mathrm{PbO},<1 \% \mathrm{SnO}_{2}\right.$ and between $15-25 \%$ alkali and alkali-earth) (Matin 2018) (Figure 1D), suggesting a different origin.

In fact, as we have commented in section 3, alkali glazes continued being produced in the Middle East, and this technology was inherited by the Islamic Iraqi potters (McCarthy 1996) (Figure 1B). Therefore, in the $9^{\text {th }}$ century in Iraq, both traditions seem to integrate into the production of alkali-lead glazes, which would eventually lead to the development of tin glazes. In fact, the Iraqi alkali-low lead glazes often show the presence of a slip-like layer made of tin oxide particles at the interface between the glaze and ceramic body (Figure 3B). Replication experiments of tin oxide (Paynter 2004) have demonstrated that this layer is formed due to the deflocculation that occurs in a high-alkali low-lead glaze (some $15 \%$ alkali with a low percentage of $\mathrm{PbO}$ ) and the subsequent settling out of tin oxide particles.

We can conclude that Roman-Byzantine (lead glazes), Sassanian (alkali glazes) and also Coptic and Levant glazing techniques (tin opaque glazes), were integrated into Iraq during the Abbasid

14 Anime and corpus are vitreous yellow and white opaque frits respectively which were added to transparent glass by Venetian glassmakers since the $15^{\text {th }}$ century.

15 Celadon is a high temperature fired glazed ware with jade-like colours. 
period, and together with Chinese influences resulted in the explosion of a new aesthetic cultural expression which later became one of the trademarks of the Islamic culture.

\subsection{Technology of production}

Here we will discuss the methods of production of tin glazes and the relationship between yellow and white glazes. The insolubility of tin oxide in a lead glaze was for long time considered responsible for the presence of unreacted cassiterite particles in the glaze. However, firing a mixture of $\mathrm{PbO}$ and $\mathrm{SnO}_{2}$ together with sand $\left(\mathrm{SiO}_{2}\right)$ gives rise first to the crystallisation of lead-tin oxide yellow particles of the $\mathrm{Pb}_{2} \mathrm{SnO}_{4}$ type, which at a higher temperature transform into yellow $(\mathrm{Pb}, \mathrm{Si})_{2} \mathrm{Sn}_{2} \mathrm{O}_{6}$ and finally, dissolve into the melt and recrystallize as white $\mathrm{SnO}_{2}$ particles (Molera 1999, Tite 2008). The range of temperatures at which those transformations happen depends on the composition of the mixture; the higher the $\mathrm{PbO} / \mathrm{SiO}_{2}$ ratio the more stable the $\left(\mathrm{Pb}, \mathrm{Si}_{2}\right)_{2} \mathrm{Sn}_{2} \mathrm{O}_{6}$ particles (Tite 2008). Consequently, the yellow glazes must contain a high $\mathrm{PbO} / \mathrm{SiO}_{2}$ ratio (typically $62-68 \% \mathrm{PbO}$ and $24-30 \% \mathrm{SiO}_{2}$ ) (Tite 2015, Matin 2018).

Nevertheless, the production of a tin glaze is referred to in the $14^{\text {th }}$ century Abü'l-Q'asim treatise on ceramics (Allan 1973), describing the production of a calcined mixture of lead and tin called calx to which sand was added. In fact, fragments of lead and tin were heated together in a crucible; melting at $181^{\circ} \mathrm{C}$. If the temperature is increased, the melt is oxidised and at a temperature above $600^{\circ} \mathrm{C}$, a mixture of lead-tin oxide, lead oxide and tin oxide particles is formed, in variable proportions depending on the original composition. This calx, added to the sand in adequate proportions, resulted in the formation of a yellow glaze containing $\left(\mathrm{Pb}, \mathrm{Si}_{2}\right)_{2} \mathrm{Sn}_{2} \mathrm{O}_{6}$ particles (Matin 2018) (Figure 4B). It has been argued that a simple increase in the relative amount of silica would result in the precipitation of $\mathrm{SnO}_{2}$ particles, and therefore, in the production of a white glaze. Nevertheless, analysis of the glazes and replication experiments have demonstrated that in the production of white glazes, plant ashes were also added to the mixture of calx and sand; the addition of alkaline salts decreasing the temperature at which $\mathrm{SnO}_{2}$ crystallises, thus enhancing the white opacity (Matin 2018).

The results obtained so far confirm that the white opaque glazes from both the Levant and Mesopotamia in the early Abbasid period were produced using calx as the main ingredient but with a different $\mathrm{Pb} / \mathrm{Sn}$ content, sand (added with different $\mathrm{PbO} / \mathrm{SiO}_{2}$ ratios) and plant ashes. The white glazes then became predominant in Mesopotamia. The influence of Chinese ceramics on the Abbasid wares, and the inability to produce true high temperature stoneware and porcelain seem to have encouraged the use of opaque white glazes. From there, white tin glazes expanded to other Islamic regions and later $\left(13^{\text {th }}\right.$ century $\left.A D\right)$ to Europe for the production of tableware, until the secret of porcelain $\left(18^{\text {th }}\right.$ century $\left.\mathrm{AD}\right)$ was unveiled. 
Yellow tin glazes continued being produced in Northern Iran, Central Asia (Matin 2018) and also in al-Andalus (Salinas 2019) in the $10^{\text {th }}$ century AD (Figure 4B) and eventually died out. Meanwhile, lead antimonate glazes started being used to decorate the multi-coloured wares produced in Egypt in the $10^{\text {th }}$ century (so-called Fayumi) (Salinas 2019b).

We have already seen that the solubility of tin oxide in alkaline glazes is the main reason why tin oxide particles had not been used for making alkali opaque glazes. However, a significant solubility of tin oxide does not only occur in alkali glazes, but also in the lead-alkali glazes used to produce the Iznik glazed wares (late $15^{\text {th }}$ century- $17^{\text {th }}$ century AD). Iznik glazes are high purity soda-lead transparent, and the decoration is of the underglaze type (see Section 7). Replication studies (Paynter 2004) have demonstrated that, in high purity soda-lead glazes, the tin oxide dissolved in the glaze during the firing, and that the subsequent recrystallization of tin oxide particles only occurred in regions with an unusually high tin oxide concentration, resulting in only a very slight opacity. The origin of the raw materials for the production of such high purity glazes has been debated for some time, but recently Tite (Tite 2016) suggested the use of a natural source of soda flux produced by the evaporation of salt-rich water from hot springs in western Turkey. These waters are characterised by relatively high amounts of boron (1000 ppm B), although this is not sufficient for the production of borosilicate glazes which are nowadays widely used for the production of glazes. Borosilicate enamels were not discovered until the $19^{\text {th }}$ century.

\section{HIGH TEMPERATURE GLAZES}

\subsection{Definition}

A high temperature glaze has a maturing temperature between $\sim 1100-1350^{\circ} \mathrm{C}$. The most typical fluxes used in historical times were alkaline earth oxides $(\mathrm{CaO}$ and $\mathrm{BaO})$. Calcium oxide can be obtained from wood ashes ${ }^{16}$ (Rogers, 1992) and can also be added as calcined and crushed lime. Nevertheless, low $\mathrm{CaO}$ high temperature glazes may be obtained adding some amounts of $\mathrm{Na}_{2} \mathrm{O}$ and/or $\mathrm{K}_{2} \mathrm{O}$ to the sand but lower than those required for a low temperature glaze. To produce a high temperature glaze, they are added as feldspar rather than as alkali salt or plant ash.

The most important factor in the development of high temperature glazes is a ceramic able to withstand the temperature. Consequently, the historical development and geographical distribution, as well as technological advances in high temperature glazes, are closely linked to

16 Wood ashes may contain up to $70 \% \mathrm{CaO}$ and also relatively high amounts of $\mathrm{K}_{2} \mathrm{O}, \mathrm{Al}_{2} \mathrm{O}_{3}, \mathrm{MgO}$, $\mathrm{Na}_{2} \mathrm{O}$, and also $\mathrm{P}_{2} \mathrm{O}_{5}$. In fact, the presence of phosphorous in a glaze is considered evidence of the use of wood ashes in its production. 
the availability of raw materials. This connects directly with the history and technology of porcelain (Henderson, J 2020 this issue).

\subsection{The historical development, geographical distribution and technological advances}

Many natural clays cannot be fired at temperatures above $1120^{\circ} \mathrm{C}-1150^{\circ} \mathrm{C}$, as vitrification becomes so extensive that the object deforms rapidly. Therefore, high temperature glazes are restricted to those bodies produced from materials which can withstand high temperatures. Among them, the most important is kaolinite ${ }^{17}$, also called porcelain clay. High temperature glazes were developed early in China ( $10^{\text {th }}$ century), either due to the presence of natural kaolinitic rich clays in the north of China (Ding ware ${ }^{18}$ ) or the availability of a natural rock in the south of China called porcelain stone ${ }^{19}$ (Yianyi 1987, Guo 1987). Highly weathered porcelain stone contains more kaolinite and was usually employed to produce the ceramic bodies (less vitrification), while less weathered porcelain stone contains more feldspar (more vitrification) and was used in the production of glazes. With varying amounts of kaolinite/feldspar, glazes and bodies were fired at the same time at temperatures between $1220^{\circ} \mathrm{C}$ and $1320^{\circ} \mathrm{C}$.

Nevertheless, the earliest Chinese glazes (from 1000 BC, extending to 1000 AD) are of the lime glaze type with firing temperatures of about $1200^{\circ} \mathrm{C}$ (the eutectic mixture of $62 \% \mathrm{SiO}_{2}, 14.75 \%$ $\mathrm{Al}_{2} \mathrm{O}_{3}$ and $23.25 \% \mathrm{CaO}$ melts at $1170^{\circ} \mathrm{C}$ ) and were applied over stoneware (Rehren 2012). Lime was initially obtained from wood ashes, although later it was also obtained from fired and crushed limestone. The addition of wood ashes increased the amount of alkalis, $\mathrm{Na}_{2} \mathrm{O}, \mathrm{K}_{2} \mathrm{O}(\sim 2-$ $3 \%$ ) but also of small amounts of $\mathrm{MgO}, \mathrm{MnO}$ and $\mathrm{P}_{2} \mathrm{O}_{5}$. The next step (Five dynasties ${ }^{20}$ whiteware glazes) was to use the modified porcelain body with burned and crushed limestone, a mixture known as glaze ash, a lime-alkali glaze type characterised by lower $\mathrm{CaO}(\sim 14 \%)$, slightly higher alkali $(\sim 3-4 \%)$ and higher $\mathrm{SiO}_{2}(\sim 67 \%)$ content, and maturing temperatures of $1220^{\circ} \mathrm{C}-1260^{\circ} \mathrm{C}$ (Wood 1999$)$.

Lime and lime-alkali glazes were transparent, and either colourless or coloured by iron, copper and titanium fired under oxidising or reducing conditions (blue, turquoise, green, yellow,

17 Kaolinite is a clay mineral with the chemical composition $\mathrm{Al}_{2} \mathrm{Si}_{2} \mathrm{O}_{5}(\mathrm{OH})_{4}$ produced by the chemical weathering of aluminium silicate minerals like feldspar. It is a layered silicate mineral, with one tetrahedral sheet of silica $\left(\mathrm{SiO}_{4}\right)$ linked through oxygen atoms to one octahedral sheet of alumina $\left(\mathrm{AlO}_{6}\right)$. It follows a series of high temperature solid-state transformations; first, metakaolinite $\left(\mathrm{Al}_{2} \mathrm{Si}_{2} \mathrm{O}_{7}\right)$ above $550-600^{\circ} \mathrm{C}$, spinel $\left(\mathrm{Si}_{3} \mathrm{Al}_{4} \mathrm{O}_{12}\right)$ above $925-950^{\circ} \mathrm{C}$, platelet mullite $\left(3 \mathrm{Al}_{2} \mathrm{O}_{3} \cdot 2 \mathrm{SiO}_{2}\right)$ and cristobalite $\left(\beta-\mathrm{SiO}_{2}\right)$ above $1050^{\circ} \mathrm{C}$ and finally transforms into a needle-shaped mullite above $1400^{\circ} \mathrm{C}$.

18 Ding wares are considered one of the first white porcelains (although it has a cream-colour), with a firing temperature above $1300^{\circ} \mathrm{C}$, produced in the North of China. The quality achieved in the Northern Song Dynasty period made it one of the greatest wares.

19 Porcelain stone is a natural rock found in the south of China composed of a mixture of quartz and fine-particle hydro-muscovite containing a small amount of feldspar and kaolinite.

20 The Five Dynasties and Ten Kingdoms period (907-979) was an era of political upheaval and division in 10th-century Imperial China. 
orange, red and black) (Wood 1999). Selecting low iron and titanium raw materials, or washing them to eliminate the iron oxide impurities was the way to obtain transparent glazes. Nevertheless, the presence of iron and titanium gave rise to a range of green to blue colours (celadon) (Kim 2011) when fired under reducing conditions, or to a yellow colour when fired under oxidising conditions. Moreover, increasing the amount of iron and combining reducing and oxidising firings, different crystalline iron oxides precipitated, which were responsible for the red, orange and black colours. Copper was also added to obtain a turquoise colour under oxidising, or red under reducing firing.

5.2 Technology and optical properties of the earliest Great Chinese productions from the Song dynasty: Jun, Ru and Guan wares

With regard to the aesthetic effect of colour, opacity and transparency among the high temperature lime glazed wares, we have to highlight some of the great early Chinese productions dating back to the Song dynasty (Kingery 1983a, Vandiver 2016) that were produced for the court, that is, Jun ware (Kingery 1983b, Hou et al 2018), Ru ware (Li 2005) and Guan ware (Wood 2015). These glazes can be semi-opaque or translucent with a medium lustre, jade-like colours (yellowish-green to blue-green), and sometimes show a beautifully crazed surface. The appearance of the glazes is mainly due to the scattering of a glassy nanostructure together with the absorption of light due to the presence of iron and titanium ions. To obtain this appearance, coarsely ground raw materials were thickly applied and slowly heated in a single firing (Vandiver 2016).

Jun ware created in the Northern Song dynasty in the first quarter of the $12^{\text {th }}$ century (Tichane 1978; Wood 1999 and 2013) is characterised by its opalescent blue glaze caused by the presence of white opaque and dark blue transparent submillimetre areas which give a three dimensional, cloudy sky-like appearance to the glaze (Figure 5). The glaze is of a lime type $(\sim 10 \% \mathrm{CaO})$ with a high $\mathrm{SiO}_{2}: \mathrm{Al}_{2} \mathrm{O}_{3}$ ratio (above 7:1), which when fired under reducing conditions at temperatures above $1200^{\circ} \mathrm{C}$ but below $1300^{\circ} \mathrm{C}$, undergoes a liquid-liquid separation (Kingery 1983a, 1986) that, after cooling, is frozen into a glass nanostructure in the form of Ca- and $\mathrm{Fe}-$ rich spherical (Figure 5E, 5H) or worm-like (Figure 5B) droplets in a $\mathrm{Si}, \mathrm{Na}$ and $\mathrm{K}$ rich matrix. The droplets scatter the light, increasing the opacity and luminosity of the glaze. Calcium richer areas with larger droplets are more opaque and, consequently, the heterogeneous distribution of calcium in the glaze is responsible for the cloudy appearance (Figure 5A and 5D). The bluish cloudy appearance is the combination of the absorption of the red light due to the presence of iron (about $1-2 \% \mathrm{FeO}$, mainly as $\mathrm{Fe}^{2+}$ ) and the scattering of the droplets' nanostructure (Hou et al 2018). Moreover, very small droplets are also prone to scattering more blue than red light, contributing also to the overall bluish colour of the glazes (Figure 5H). The addition of reduced 
copper either splashed over the surface or as an overall glaze, imparts a red colour, which together with the blue colour of the glazes, produces a range of colours; red, violet, purple and pink. The incorporation of $\mathrm{Al}_{2} \mathrm{O}_{3}$ from the ceramic into the glaze decreases the $\mathrm{SiO}_{2}: \mathrm{Al}_{2} \mathrm{O}_{3}$ ratio (Figure 5C) which is not high enough for the development of the glaze nanostructure at the glaze-ceramic interface. Besides, titanium from the ceramic body is also incorporated into the glaze with the consequent increase in the $\mathrm{Fe}^{3+} / \mathrm{Fe}^{2+}$ ratio and the transformation of $\mathrm{Ti}^{4+}$ into $\mathrm{Ti}^{3+}$. As a consequence, a transparent brownish glaze layer is formed at the glaze-ceramic interface (Figure 5G) providing a dark background to the Jun glaze which enhances the colour and increases the three dimensional perception.

Contemporary $\mathrm{Ru}$ stoneware glazes with a subtle green colour are also of a slightly underfired $\left(\sim 1200^{\circ} \mathrm{C}\right)$ lime type, but with a $\mathrm{SiO}_{2}: \mathrm{Al}_{2} \mathrm{O}_{3}$ ratio, 3-4:1. This leads to crystalline micro-needlelike precipitates of anorthite $\left(\mathrm{CaAl}_{2} \mathrm{Si}_{2} \mathrm{O}_{8}\right)$ and, subsequently, to an amorphous liquid-liquid separation glaze nanostructure (above $950^{\circ} \mathrm{C}$ ) (Li 2005, Reedy 2016). The anorthite crystallites and the glaze nanostructure scatter light very efficiently, and the very thin glaze appears opaque, smooth and even; the colour between green to bluish-green is due to the presence of $1-2 \% \mathrm{FeO}$ and $<0.2 \% \mathrm{TiO}_{2}$.

Guan wares were made in the second half of the $12^{\text {th }}$ century and into the $13^{\text {th }}$ century for the Southern Song (AD 1127-1279) court. Guan wares show a very thick glaze (up to $2 \mathrm{~mm}$ ) over a very thin body, with a jade-like smoothness and semi-opacity and a crazed surface. Glaze crazing was intentionally sought using low contracting ceramic bodies and thick glazes similar to those of $\mathrm{Ru}$ glazes, but with a slightly higher $\mathrm{SiO}_{2}: \mathrm{Al}_{2} \mathrm{O}_{3}$ ratio, 5-6:1, and appearing to be underfired $\left(950^{\circ} \mathrm{C}-1200^{\circ} \mathrm{C}\right)$ (Wood 2015$)$. The glazes are characterized by a multi-layered ( 2 to 4 layers) glaze structure with fine trapped bubbles and undissolved quartz, as well as precipitates of both granular and quite long needle-like anorthite together with the glass nanostructure, formed during the firing process (Reedy 2016). The colours are very varied from yellowish-green to bluish-green due to the presence of $<1 \% \mathrm{FeO}$ and $<0.3 \% \mathrm{TiO}_{2}$.

The development of a liquid immiscibility and, consequently, a glass nanostructure was one of the outstanding achievements (although not the only one) of Chinese potters. They obtained ceramics solid as rocks and beautiful as gemstones, with subtle colours, jade like smoothness, semi-opacity and a tridimensional quality, which makes them unique.

\section{DECORATIONS AND DECORATIVE METHODS}

Previously, we described (section 2.2) the colours obtained from main chromophore elements ( $\mathrm{Fe}, \mathrm{Mn}, \mathrm{Cu}, \mathrm{Co}$ and $\mathrm{Cr}$ ) dissolved in the glaze to give an overall colour to the glaze (Figure 2). We also discussed that the colours obtained depend on the glaze composition, the compositions of the compounds incorporating the chromophores (pigments), and the firing conditions 
(temperature and atmosphere). In this section, we discuss the different methods by which these chromophores could be applied in order to produce the observed polychrome decoration. We can distinguish four main different decorative techniques depending on how the colours were applied: side-by-side, underglaze, in-glaze and overglaze (Figure 6). Moreover, we have also discussed the use of white or colour slips to mask the ceramic colour before applying the glaze (Figure 7). Finally, other decorative techniques include enamelling (Figure 8) and lustre painting (Figure 9).

\subsection{The side-by-side technique}

Side-by-side consists of painting different areas of the decorative motif with different coloured glazes directly onto the surface of the ceramic surface. This technique was first used for the Fayumi polychrome glazes between the $10^{\text {th }}$ and $12^{\text {th }}$ centuries in Egypt (Salinas 2019b); in which adjacent radial or spoked bands of up to five colours of yellow/amber, green, turquoise, brown and white lead glazes were applied, the yellow and green glazes being opacified with lead antimonate, and the turquoise and white with tin oxide (Figure 6A).

Another example of this technique is provided by "Cuerda seca" meaning "dry cord". A typical decoration invented in Islamic Spain in the second half of the $10^{\text {th }}$ century with its maximum propagation in the $12^{\text {th }}$ century, in which different colour glazes are separated by a brown/black line made of a manganese and iron rich slip. The coloured areas could cover the whole surface of the object and was called total, or only part of the surface and was called partial. The provenance of this decorative technique is still under debate, from possible parallels found in Suza (Iran) from the Ummayad period (Soustiel 1985), to being an Andalusian innovation, with a subsequent diffusion into Northern Africa (Moreno 1987). Nevertheless, its Andalusi preeminence is unquestionable. Little analysis has been carried out of these glazes, both transparent yellow (iron) and green (copper and iron) lead glazes, and turquoise (copper) and white tinopacified glazes are combined on the same piece (Pérez-Arantegui 1999, Chapoulie 2005, Déléry 2006). Nevertheless, exceptional multi-coloured (turquoise, blue, green, yellow, amber, white) cuerda seca tilework from Iran dating to the late $14^{\text {th }}$ century should be mentioned. In this case, the black lines and the colour glazes were applied over a white tin glaze (O'Kane 2011).

The side-by side technique was used in the south of China for the cizhou (since the mid $14^{\text {th }}$ century) and in the north for the fahua $\left(15^{\text {th }}-16^{\text {th }}\right.$ centuries $)$ wares. The former consist in colourful decorated alkali glazes of the lead-potash type (copper dark green, cobalt, manganese blue-black and lead-rich iron amber) applied directly over the slipped stoneware. The latter followed a method similar to those used to produce the cloisonné metalwork (fahua ware, 
meaning designs with boundaries). A thin-trailed slip "fence" was attached to the ware separating "cloisons", areas which were filled with crushed coloured lead-potash glass mixed with some gum. The main novelty was the introduction of an aubergine colour containing cobalt, manganese, copper and iron (Henderson 1989, Wood 1999). Although initially, fahua wares were produced in the North of China, by the mid $15^{\text {th }}$ century they had spread to the south where they were produced over hard-fired porcelains, then the colour glazes were applied directly over the ceramic bisques. A similar technique was used in the $15^{\text {th }}$ century in Seville (Spain) for the "cuenca y arista" tile work meaning literally "basin and ridge" (Coentro 2020).

\subsection{The Underglaze technique}

Underglaze consists of painting the unfired ceramic pot with the pigments before the first firing (biscuit), (Figures 7E, 7F, 7G, 7H). After firing the decoration is fixed onto the ceramic body and cannot be removed by washing. Afterwards, a glaze is applied over the decorated biscuit by pouring or immersion in a water suspension of the glaze components, and the ceramic is fired for a second time. For high temperature glazes double firing is not necessary as the glazes also hold high temperatures and a single firing is normally used. This decorative technique is easy to apply and produces sharply-defined designs. Transparent glazes are commonly applied over underglaze decorations, but as some pigments, such as for instance, cobalt, manganese and iron, have a high diffusivity, an opaque tin glaze could be applied without losing much colour saturation. A defined contour is not easy to obtain with copper, which spreads out excessively (but it could be achieved in ancient times). For instance, underglaze decorations were used over slipped wares since the $10^{\text {th }}$ century (Iran and Central Asia) (Figure 7). Chromium black decorations under alkali glazes were also produced in Syria and Iran, and later extended to the production of cobalt blue decorated ceramics from the $12^{\text {th }}$ century (Iran and Syria) (Mason 2001). Underglaze decorated wares also include $13^{\text {th }}$ century manganese brown and copper green decorated ceramics, the so-called Protomajolica (Patitucci Uggeri 1985) and Majolica Archaica (Blake 1980) in Italy, Pisa from Barcelona (Beltrán de Heredia, 2007) and $14^{\text {th }}-15^{\text {th }}$ century cobalt blue decorated ceramics from Christian and Islamic workshops in Spain and Portugal (Coentro 2012). As a result of this method of application, a reaction between the pigment, the ceramic body and the glaze, results in the formation of crystalline compounds, pyroxenes incorporating the colouring elements (manganese, chromium, cobalt, iron), manganese and iron lead silicates (kentrolite-melanotekite ${ }^{21}$ ), manganese silicate (braunite ${ }^{22}$ ),

21 Kentrolite-melanotekite series, $\mathrm{Pb}_{2} \mathrm{Mn}_{2} \mathrm{O}_{2} \mathrm{Si}_{2} \mathrm{O}_{7}-\mathrm{Pb}_{2} \mathrm{Fe}_{2} \mathrm{O}_{2} \mathrm{Si}_{2} \mathrm{O}_{7}$, are formed around decomposing particles of manganese or iron oxide in a lead glaze at a firing temperature below $925^{\circ} \mathrm{C}$ (Di Febo $2017 \mathrm{~b}$ ).

22 Braunite, $3\left(\mathrm{Mn}_{2} \mathrm{O}_{3}\right) \cdot \mathrm{MnSiO}_{4}$, formed by the reaction of manganese with the silica of the glaze. 
manganese and iron oxides of the colouring elements (bixbyite ${ }^{23}$, haussmanite ${ }^{24}$, haematite $^{25}$ ) (Molera 2013, Di Febo 2017). Although cobalt completely dissolves into the glaze, arsenic is a common impurity of cobalt pigments from Erzebirge (Germany), and therefore, calcium-lead arsenates are often found in the glazes (Figure 6E, 6F, 6G and 6H) (Viti 2003; Pradell 2013).

Cobalt blue decorations and also copper red with limited success were also applied underglaze on stoneware and porcelain in China during the Ming dynasty (de Waal 2007). As a result of the interaction between the cobalt pigment and the porcelain/stonepaste body, the presence of cobalt aluminate $\left(\mathrm{CoAl}_{2} \mathrm{O}_{4},\right)$ is observed.

\subsection{The in-glaze and overglaze techniques}

In-glaze consists of painting with the pigment dissolved in water (probably mixed with some fluxing compounds to facilitate the integration) directly over the raw glaze. As painting over a powdered glaze layer is not easy, this method requires a more skilled potter. It was commonly used for splashed decorations. Pigments were applied on top of the glaze from early in the Islamic period, notably on the green and blue-painted wares of $8^{\text {th }}$ to $10^{\text {th }}$ century Iraq (Mason 1997).

Overglaze refers to the application of a glassy coloured layer to the surface of the glaze. This kind of decorative technique has been identified in some finely detailed green and black decorations in al-Andalus from the end of the Emirate and into the Caliphal period (late $9^{\text {th }}$ and $10^{\text {th }}$ century) (Molera 2009, Molera 2013, Salinas 2018) (Figure 6C and 6D). Transparent high lead glaze colour decorations applied over a high lead transparent glaze, switched to tin opaque colour decorations over a white tin glaze during the Emirate (Salinas 2018). The decorations show the same basic composition as the underlying glaze except for the chromophore elements. The glazes and decorations underwent a single firing.

Mina'i decorations from Iran ( $12^{\text {th }}$ century) (Mason et al 2001, Freestone 2002) might also be included, as the composition of the glassy part of the polychrome decorations is the same as that of the underlying glaze. However, in this case, the glaze was fired prior to the application of the decorations which were subjected to a short, high-temperature second firing.

Later from the early $15^{\text {th }}$ until early $17^{\text {th }}$ century in Italy, polychrome Majolica was produced by painting the pigment over the raw opaque glaze, then a transparent raw lead glaze known as

23 Bixbyite, $(\mathrm{Mn}, \mathrm{Fe})_{2} \mathrm{O}_{3}$; is formed firing pyrolusite $\left(\mathrm{MnO}_{2}\right)$ at a temperature below $950^{\circ} \mathrm{C}$

24 Haussmanite, $\mathrm{Mn}_{3} \mathrm{O}_{4}$; is formed firing pyrolusite $\left(\mathrm{MnO}_{2}\right)$ at a temperature above $950^{\circ} \mathrm{C}$.

25 Haematite, $\mathrm{Fe}_{2} \mathrm{O}_{3}$; the presence of small crystallites gives a red colour. If it grows as large hexagonal platelets, it gives a sparkling glow to the glaze (aventurine glazes). 
coperta was applied over it (Tite 2009) and the piece was subjected to a single firing. The decorations incorporated cobalt blue and antimony based yellow decorations. This technique expanded to the rest of European productions (Coentro 2012, Pradell 2013, Coentro 2020).

\subsection{The Slip painting}

Slips were widely used in the Byzantine Empire (Armstrong 2018, Vroom 2006) and Islamic territories (Whitcomb 1989, Scanlon 1998, Fehérvári 2000) giving rise to a multicoloured slipped ware, then, painted decorations and transparent glazes started being applied over the slipped wares.

Some Byzantine glazed red wares and white wares dating from the $10^{\text {th }}-13^{\text {th }}$ centuries are described as slipped (Armstrong 2018, Vroom 2006, Palamara 2016), and the glazes are, in all the cases, high lead. Some more detailed analysis of white wares from the $14^{\text {th }}$ century AD (Turkey) (Waksman 2017) showed that the slips were thick $(100-200 \mu \mathrm{m})$, made of clay and quartz, the clay being different from that used in the ceramic body.

Similarly, ceramics found in Iran and Uzbekistan (Henshaw 2010, Holakooei 2019, Molera 2020) dating from the $9^{\text {th }}-12^{\text {th }}$ century $A D$, also have a high lead glaze over a slip made of a mixture of sand and an aluminous rich (and in some cases also potassium rich) clay different from those of the ceramic body. In the $13^{\text {th }}$ century, a complete change in the materials occurred and alkali glazes applied over a quartz-rich slips were used (Molera 2020) (Figure 7D, 7E, 7F).

Early Islamic glazed slip wares were also found in Egypt, also called Coptic ware $\left(8^{\text {th }}-9^{\text {th }}\right.$ century AD) (Whitcomb 1989, Scanlon 1998). Some were also found in the Levant (Palestine, Jordania) (Taxel 2014) and have been analysed, indicating a thin (10-20 $\mu \mathrm{m})$ clayish slip made of the finer fraction of the same kaolinitic clay used for the ceramic (Ting 2019). As the slips were in all cases aluminous rich, lead-potassium feldspars grow at the interface between the slip and the glaze (Figure 7).

Sgraffitto wares were produced by scratching the surface of the slip and allowing the ceramic to show up through the glaze (Figure 7A, 7B, 7C).

In the south of China since the mid $14^{\text {th }}$, the cizhou wares, colourful decorated lead-potash glazes were also applied over the slipped stoneware.

\subsection{Enamel}

Enamels are fused low temperature colour glazes over high temperature glazes (Figure 8). The enamels are fired in a second firing at a lower temperature than for the underglaze and the ceramic body. The composition of the enamels is necessarily different from those of the underlying glazes. Therefore this type of decoration is applied mainly on stoneware and porcelain. The earliest enamels were produced in China to colour porcelain from the $13^{\text {th }}$ 
century (Li 2010, Wen 2017) and started to be extensively used when they were referred to as famille-vert and famille-rose (Miao 2010, Kingery 1986 and 1986b, Van Pevenage 2014, Giannini 2017, Colomban 2017a,b), and in European porcelains (Maggetti 2017, Colomban 2001 and 2004). The enamels are of two types; lead free or low lead, and high lead-based (Figure 8). In both cases they are similar to the enamels used for metal and glass (Freestone 2002). There is evidence of the use of European enamel in Chinese porcelains (Giannini 2017).

\subsection{The lustre}

Lustre is a micrometric layer made of silver and/or copper metallic nanoparticles lying beneath the glaze surface (Figure 9), which shows a large variety of colours (green, yellow, amber, red, brown, white) with a metallic (golden, coppery, silvery) and iridescent (bluish, purplish) appearance, (Figure 9). It is formed by the reaction between a lustre pigment with the glaze in a separate low temperature firing. Since the lustre pigment is applied over a previously fired glaze, the process often involves three firings: the first for the ceramic bisque, the second for the glaze and the third for the lustre.

A lustre pigment is constituted basically of salts of copper and silver, a sulphur compound (mercury sulphide, cinnabar, copper, iron and arsenic sulphide or iron/copper sulphates), tin/lead calx and Arabic gum substituted in later recipes by a clay rich in iron oxides. The pigment was applied by a brush over the glaze surface. The ceramic was then heated up to relatively low temperatures $\left(550^{\circ} \mathrm{C}-600^{\circ} \mathrm{C}\right)$, above the glass transition temperature but below the softening point of the glaze. After the final firing, the lustre pigment residue is rubbed off revealing the lustre layer beneath. The mechanism by which silver and copper compounds react with the glaze surface is what is known as "ionic exchange", which happens between the silver ions $\left(\mathrm{Ag}^{+}\right)$, but also the copper ions $\left(\mathrm{Cu}^{+}\right.$or $\mathrm{Cu}^{2+)}$ from the lustre paint, and the sodium $\left(\mathrm{Na}^{+}\right)$ and potassium $\left(\mathrm{K}^{+}\right)$ions from the glaze (Pradell 2005). The reducing gases produced by a wood kiln during the final heating stage are responsible for the reduction of the silver and copper ions into the metallic state and the precipitation of the metal nanoparticles, copper $\left(\mathrm{Cu}^{\circ}\right)$ (Figure 9G) or silver $\left(\mathrm{Ag}^{\mathrm{o}}\right)$ (Figure $\left.9 \mathrm{H}\right)$. However, the addition of reducing agents to the glaze, such as $\mathrm{Sn}^{2+}$ or $\mathrm{Fe}^{2+}$, also favours the precipitation of the metal particles. In fact, silver is very easily reduced to the metallic state, contrarily to copper which commonly presents mixed oxidation states $\left(\mathrm{Cu}^{+}\right.$, $\mathrm{Cu}^{2+}$ and $\mathrm{Cu}^{\circ}$ ) depending on the firing conditions (Figure 9I). The final colour shown by the lustre layer depends on the amount and the ratios of silver and copper, the oxidation state of copper and on the size of the nanoparticles. The colour of silver lustre layers varies from green to yellow when the size of silver nanocrystallites increases from $10 \mathrm{~nm}$ to $50 \mathrm{~nm}$ (Figure 9J, 9K). Copper lustres are red (Figure 9J, 9K). Moreover, scattering becomes important for large 
particles (above $50 \mathrm{~nm}$ ), and this is responsible for the bluish iridescences shown by some silver lustre decorations (Pradell 2016).

The thickness of the lustre layer is directly related to the diffusivity of copper and silver into the glaze surface. Considering that the addition of $\mathrm{PbO}$ to an alkali silicate glass decreases the ionic mobility, thinner lustre layers are obtained on lead-alkali glazes, with the consequent accumulation of metal nanoparticles in the surface layer (Molera 2007). This is responsible for the golden/coppery metallic-like shine shown by the lustre layers (Pradell 2012). Consequently, the addition of lead to the glazes favours the development of the metallic appearance provided that the adequate firing protocol is followed (Molina 2014). The merging of the nanoparticles into large particles results in a silvery or dark dull appearance of the layer (Pradell 2018).

Lustre is an Islamic technological innovation. The first lustre decorations were applied on glass, the earliest identified objects dating to between 772 AD and 779 AD (Brill 1979, Carboni 2002). Those lustre painted glass objects were produced in Egypt or Syria and probably dated earlier (maybe as early as the $6^{\text {th }}$ century AD). There is quite wide agreement among scholars that lustre decorated glaze ceramics started being produced in the $9^{\text {th }}$ century in Iraq, under the Abbasid rule (750-1258 AD) (Watson 1985, Caiger-Smith 1991). Künel (1934) reconstructed the sequence from earliest to latest: polychrome (brown-green-amber) lustres (Figure 9C), bichrome (red-black, red-yellow or red-silvery and brown-green) (Figure 9A), and monochrome green lustres (Figure 9D). From the Abbasid period, the main lustre production moved to Fatimid Egypt (901-1171 AD) (Figure 9E) and then expanded to other places in the Mediterranean, first to Tunisia (Waksman 2014) and Al-Andalus (REMAI 2012, Rosser-Owen 2010) before the second half of the $11^{\text {th }}$ century, and to Syria (Figure 9F) (Porter 1987, Pradell 2018 ) in the first half of the $12^{\text {th }}$ century and after the defeat of the Fatimids, to Iran (Watson 1985). The expansion continued later in the $14^{\text {th }}$ century to the Christian kingdoms in Spain (Pérez-Arantegui 2001) (Figure 9B) and in the $16^{\text {th }}$ century to Italy (Padeletti 2004). All the post-Abbasid productions are monochrome of varying colours (green, yellow, brown, red) with exception of the Italian lusterware which has two colours, red and yellow.

\section{GLAZE ALTERATIONS}

One of the main problems when analysing glazes is the alterations they often suffer (Figure 4A). Glass corrosion due to the presence of an aggressive environment is a well-known problem which affects the appearance and integrity of glasses found in archaeological sites; and the same happens for glazes. However, the fine thickness of the glazes (a few hundred microns) increases the magnitude of the alteration/corrosion problem (Figure 4). Many glasses are thick enough, so that after removing the alteration layer it is still possible to analyse unaltered portions of the 
glass object. On the contrary, this is never true for glazes, as the whole glaze thickness is affected to a greater or lesser extent.

The kinetics of the reaction of the glass surface have been determined for historical glass objects in laboratory corroding conditions. In alkaline glasses, typical altered glass layers of $\sim 1 \mu \mathrm{m}$ thick are found after six years of exposure time to a wet environment (Melcher 2001); similar or even thicker leached layers are found after only $162 \mathrm{~h}$ for lead glasses (Wood 1978); in fact, lead leaching in an acidic humid environment is known to have been one of the main arguments for the prohibition of lead glazed objects for culinary uses. Consequently, in alkaline glazes we should expect the whole glaze to be affected after 1000 years of exposure to a humid environment, while for lead glazes after only 100 years. Even glazed cooking pots or tableware ceramics kept in museums might have contained liquids and food for their life period, tens of years, and therefore are expected to show some degree of alteration. Consequently, the effect of burial and life conditions on the chemical composition of the glazes is a very important factor which has to be taken into account when analysing a glaze.

Aqueous corrosion in alkaline glass is based on a glass dissolution-silica precipitation reaction which involves a complex process. The process is driven by a diffusion-controlled ion exchange front, involving the inward diffusion of $\mathrm{H}^{+}$coupled to an outward diffusion of alkali and alkali earth ions. In lead glass, neutral and acidic media corrosion also involves an inter-diffusion controlled lead leaching and silica dissolution/re-precipitation. The altered surface layer formed is composed of a so-called 'hydrated glass' depleted of alkalis or lead. The microstructure of the altered glazes often resembles those of altered glass: a layered structure formed by a sequence of micrometric silica-rich sheets of glass with a composition depleted of alkalis/lead, as can be seen in Figure 4B. It is also not uncommon that the total chemical composition determined by Energy Dispersive Spectroscopy (EDS) attached to a Scanning Electron Microscope SEM or Electron Probe Micro-Analyser (EPMA), also called Microprobe, give totals above $100 \%$ due to the peculiar layered structure. It is also very common that the interface between the glaze and the ceramic body appears heavily altered (Figure 4B and 4C).

The dissolution of the glaze in an environment of stagnant water also results in the precipitation of secondary insoluble phases, such as calcium and lead carbonates, sulphates and phosphates, like those seen in Figure 4 (Lenting 2018). Those compounds may appear formed on the surface of the glaze, on the interface between the glaze and the ceramic, or inside the cracks and bubbles, as can be seen in Figure 4A and 4C. This is also another characteristic of the alteration process and something to take into account when interpreting the analytical data obtained. Some of the compounds found, such as lead carbonate, may erroneously be interpreted as original 
unreacted compounds, and lead to incorrect conclusions (Figure 4D). If the glazes are coloured, the colouring ions will also be released by the dissolution of the glaze and fixed by reprecipitation of new insoluble compounds at the surface of the ceramic, incorrectly suggesting the application of an overglaze decorative layer.

To all this we have to add that many glazed fragments collected from workshop wasters were in fact thrown away because of misfiring; both over or under-fired objects will have glazes with a chemical composition differing from those of the ceramics produced in the workshop. Nevertheless, the study and analysis of over or under-fired glazes may also supply information about the materials used and methods of application of the glazes which will also be of much value in the unveiling of technological aspects. Over-fired glazes may show lead or alkali volatilisation and an excess of elements incorporated from the ceramic. Under-fired glazes may show undissolved particles, which can give direct information on the original raw compounds, or may appear unmolten and show a crystalline structure.

\section{HOW TO ANALYSE A GLAZE?}

\subsection{Methods of preparation}

As many different elements (chemical composition, colourants, crystalline particles present) or properties of the glazes (colour, brilliancy, opacity, hardness, glass transition temperature, softening point, etc) might be of interest, it is important to establish an order of priority, as each of them may require of specific preparation methods and analytical techniques. Nevertheless, an examination of the entire glaze surface should be performed first, including the observation of the surface with a Stereomicroscope and UV-Vis-NIR spectroscopy for colourants and colour analysis.

However, glazes, like glasses, are often heavily weathered, but contrarily to glass, the altered layer often affects the whole glaze thickness and therefore, cannot be removed. Even for those glazes not showing evident symptoms of alteration, the outer surface is affected by firing and burial conditions, and consequently, an analysis obtained directly from the glaze surface should normally be disregarded. It is also true that this is less important for high temperature glazes which appear normally pretty well preserved. This obviously limits the use of non-invasive chemical analytical techniques. Cross sections of the glazes will be needed to identify the areas suitable for analysis and for the investigation of the microstructure of the glaze. Consequently, micro-analytical techniques will normally be required. Moreover, these techniques need of polished surfaces and, in order to have access to the inner parts of the glazes, of polished cross- 
sections. Polished cross sections are obtained by embedding a small fragment of the glazed ceramic surface in a bloc of resin. The surface can thus be ground and polished by first using a succession of grinding papers of decreasing particle size (silicon carbide of successive grits) and secondly, a succession of cloths impregnated with a water suspension of diamonds of decreasing particle size $(3 \mu \mathrm{m}, 1 \mu \mathrm{m}, 0.5 \mu \mathrm{m}$, etc).

Polished cross sections are normally required both for Optical Microscopy (OM) and Scanning Electron Microscopy (SEM) observation. Moreover, major elemental analysis of selected areas of the glazes can be then obtained with Energy Dispersive Spectroscopy (EDS) using a detector attached to the SEM; minor elements composition may be obtained using an Electron Probe Micro-Analyser (EPMA) or Microprobe, basically a SEM designed to be optimized for analysis, using a set of attached higher resolution Wavelength Dispersive Spectroscopy (WDS) detectors attached. Trace elemental analysis and also isotope identification might be obtained from the same polished cross-section with Laser Ablation Ion Coupled Plasma Mass Spectroscopy (LAICP-MS) and also by $\mu$-Particle Induced X-ray Emission ( $\mu$-PIXE). $\mu$-X-Ray Fluorescence Spectroscopy ( $\mu$-XRF) with synchrotron light has also the capability of producing qualitative 2D distribution elemental maps. Crystallite precipitates and glaze structure determination might be obtained also by Raman Spectroscopy from the polished cross sections.

Thin cross sections are required for the observation in a petrographic Optical Transmission Microscope which is an inexpensive technique which gives very useful information about the glaze microstructure, in particular those crystals that are not on the polished surface (embedded into the glaze). Thin cross sections are also required for $\mu$-X-ray Diffraction ( $\mu$-XRD) analysis of the crystalline precipitates, and finally, polished thin cross sections may also be used for the Optical Microscope observation in reflection mode and for the SEM.

Finally, in some cases, in particular with decorations that involve the presence of precipitates with nanometre size (nanoparticles), OM and conventional SEM are not sufficient and it is necessary to use other visualization techniques, such as Field Emission SEM (FE-SEM), Scanning Transmission Electron Microscopy (STEM) or Transmission Electron Microscopy (TEM), each of which require of specific sample preparation. FE-SEM requires an ultrapolished surface, which is normally obtained using an ion beam, although some FE-SEM also have a Focus Ion Beam (FIB) coupled to the microscope with which it is possible to cut and polish a surface down to the required flatness inside the same SEM chamber. STEM and TEM require of a thin section with an ultra-polished surface which can be obtained using an external ion beam, or a FIB. FE-SEM and STEM facilities are sometimes coupled with a FIB in the same 
microscope, in which case, the samples can be cut, thinned and polished to the desired final grade using the FIB and subsequently visualised using the FE-SEM or the STEM.

\subsection{Microstructure}

The microstructure found in the glazes results first of all from the reaction between the glaze components and with the environment during use or burial, and second, from the reaction between the glaze melt and the ceramic body.

Low magnification (stereo microscope) of the glaze surface is the best way to observe bubbles and crack patterns, as well as undissolved grains and neo-formed crystals emerging on the surface. Surface morphology related to the overglaze decorations, and last but not least, the corrosion of the glaze can also be observed in a similar manner.

The microstructures can be seen at higher magnification in glaze cross sections in the OM (Figure 10) and SEM. Reflected light microscopy is often referred to as incident light, epiillumination, or metallurgical microscopy, and is the method selected for specimens that remain opaque even when thinned to 30 microns, or for thick polished sections as those used in SEM. Many microscope manufacturers offer models that permit alternate transmitted (Figures 10A and B) and reflected illumination (Figures 10C, 10D, 10E and 10F) which is very useful. In Brightfield (Figures 10E and 10F), the sample is illuminated from above through the objective, Brightfield images being similar to SEM images (except that the contrast is not related to the average molecular weight of the compounds). Darkfield images (Figure 10C, 10D) are used to enhance the contrast collecting only the scattered light, giving colour images which are very useful for studying decorations (underglaze/overglaze, etc.) (Figure 7).

However, such bi-dimensional images do not reflect the volume of the glaze layer; hence thin cross sections (typical depth of $30 \mu \mathrm{m}$ ) which can be observed in transmission OM are also required to give a 3D image, and help visualize the 3D morphology of the crystals which, depending on the geometry (1D and 2D structures like needles and platelets), are difficult to see in a polished cross section, (Figure 10A and B). Polarizing light microscope uses two types of light: plane polarized light (PPL), which is similar to regular transmitted light, and crossed polars light (XP) in which the light is polarized in two directions (normally at $90^{\circ}$ ) and interacts with the mineral crystallites producing interference colours and extinctions used for the identifications of minerals (Quinn, 2013, Reedy 2016, Di Febo 2017).

SEM also has various imaging methods: Secondary electrons image (SE), Backscattered electrons (BSE) images (Figure 7 and 8). Topographic images may be obtained using secondary 
electrons; it is of interest to observe the presence of cracks, bubbles and the surface of the glazes. Backscattered electrons (BSE) images, which have atomic weight contrast, are of more interest; they show chemical contrast, with darker or lighter areas being associated with lower and higher average molecular weight, respectively. Those images are useful in identifying structures with different chemical compositions, such as original undissolved particles, neoformed crystallites, etc. Nevertheless, as secondary electrons are also emitted from areas with a higher average molecular weight, secondary images also show some chemical contrast (all the figures). Generally speaking, secondary electrons are emitted from areas some nanometres below the surface, this is why they provide a higher lateral resolution and give topographic contrast images. Backscattered electrons have higher energy and are scattered from areas of the sample some micrometres below the surface. Therefore, they provide lower lateral resolution. Moreover, to excite heavy elements such as lead, more energy associated with typical acceleration voltages of $15-20 \mathrm{kV}$ is required. However, high acceleration voltages result in deeper penetration into the surface, and therefore a reduction of the lateral resolution and consequently, the capacity of resolving small structures.

Chemical images can also be obtained using an Energy Disperse X-ray Spectroscopy (EDX) detector attached to the SEM. These detectors collect the X-rays emitted by the sample to the de-excitation of the atoms interacting with the electron beam. The X-rays emitted have characteristic energies associated with the chemical elements present in the sample. By selecting the X-rays associated with particular elements, it is possible to obtain a 1D or 2D map for each element present (Figure 5, Figure 8). Similarly, $\mu$-X-Ray Fluorescence Spectroscopy ( $\mu$-XRF) with synchrotron light also has the capability of producing qualitative $1 \mathrm{D}$ and $2 \mathrm{D}$ distribution elemental maps (Cotte 2010, Pradell 2016, Wen 2017).

In order to increase the lateral resolution and discriminate smaller structures, it is necessary to reduce the penetration of the electron beam, therefore reducing the acceleration voltage (2-5 $\mathrm{kV}$ ), but in such a situation we only obtain secondary electron images. Some SEM called Field Emission SEM (FESEM) have an electron gun (Schottky), which emits a narrower and more monochromatic beam which can discriminate structures of only a few nanometres in size $(\sim 5$ $\mathrm{nm})$. Nevertheless, the surface of the sample has to be polished accordingly. Mechanical polishing has some limitations and the quality of the surface can be improved by ion gun polishing. A Focus Ion Beam (FIB) gun may also be attached to a FESEM which can be used to cut and polish a surface for observation with the FESEM, or to extract a lamella for observation with a Transmission Electron Microscope (TEM). TEM uses a high energy (200-300 keV) electron beam and has atomic resolution, but needs a thin sample transparent to the electrons (50-60 nm thick). 
Such high polishing and high resolution images are necessary when the glazes show low chemical contrast structures and/or nanometric structures. One important advantage of the FESEM- FIB technique is that it allows the selection of the exact area to be observed with micrometric resolution. It has been successfully used in the analysis of liquid-liquid separation nanostructures in the different coloured areas from Chinese stoneware glazes (Figure 5) and also for the observation of the metal nanoparticles in micrometric surface lustre layer decorations (Figure 9). Acid etching of the glazes were used before FIB and FESEM microscopes became available for the determination of low contrast micro/nanometric structures. However, the limited control of the acid etching of the glaze surfaces does not allow a precise selection of the area for observation and makes it almost impossible to study differently coloured areas. In addition, after acid etching, the polished surface is lost and the chemical analysis becomes unreliable.

\subsection{Chemistry}

The chemical analysis of glazes, undissolved particles and neo-formed crystallites should be performed by selecting the areas/spots of interest and avoiding alteration, bubbles and cracks. Consequently, the analyses should be obtained over the polished glaze cross section, selecting the areas of interest and using micro-analytical techniques. SEM-EDS or Microprobe are the most common techniques available, SEM-EDS being adequate for elements present in major and minor amounts with a typical detection limit of about $0.1 \%$. However, this limit can be reduced when overlapping between emission lines occurs, such as in the case of metals and heavy elements (i.e. $\mathrm{Pb}$ and $\mathrm{S}, \mathrm{Mg}$ and $\mathrm{As}, \mathrm{Na}$ and $\mathrm{Cu}$ or $\mathrm{Sn}$ and $\mathrm{Sb}$ ). The Microprobe has a higher accuracy (about $0.01 \%$ ) and higher reliability for overlapping elements. The use of high energies $(20 \mathrm{kV})$ appropriate for the detection of heavy elements also limits the accuracy in the determination of light elements $(Z<10)$, such as lithium or boron. This is particularly important because light elements, even when they are a main compound, form a low total weight of the glaze, and therefore, they are rarely present in high amounts. This is one of the reasons why boron has rarely been determined.

Considering the heterogeneous nature of the glaze, not only because of the presence of particles and crystallites due to the interaction of the glaze with the ceramic body, different types of analysis may be performed. Spot analysis is performed focusing the electron beam on different points of the glaze (near the surface or near the interface) and on the particles and crystallites. We have to take into account that the spot is not dimensionless, but has a pear shaped volume, the depth analysed depending mainly on the energy of the beam, while the surface area analysed depends mainly on the element and the energy of the X-rays detected. Typical volumes are of 
about 1-5 $\mu \mathrm{m}$ depending on the material and electron beam energy. This limits the size of the smallest crystallite or particle which may be analysed, but also the smallest glaze heterogeneity that may be determined.

For glasses and glazes a very important problem which has to be taken into account is the mobility of some elements, such as the alkali, and in particular sodium. This can be avoided by measuring an area instead of a spot, or by slightly defocussing the electron beam.

LA-ICP-MS has emerged as a powerful microanalytical technique able to determine trace elements (Gratuze 2001). Many colourants are present in minor or trace amounts (Giussani 2009, Zhu 2015, Bao 2015, Giannini 2017). Moreover, trace elements related to the sand or raw materials used are also of high interest. In addition, it is useful for the determination of boron, normally present in small amounts and coming from many natural flux sources (Tite 2016), but also deliberately added to reduce the firing temperature in enamels (Boron in Cloisonne).

PIXE and in particular $\mu$-PIXE beams are also capable of measuring trace elements (Biron and Beauchon 2003, Bouquillon 2005, Coentro 2013). The main problem is that it requires a high energy proton beam.

A quantitative chemical composition of the glaze and of the particles present can be obtained, provided that the detector system is calibrated. The calibration of the detectors is normally performed using mineral and/or glass standards (standardization) specifically selected to match the glaze compositions to be determined as much as possible. Once the standardization is performed, its validity has to be verified measuring secondary glass standards comparable in composition to the range of compositions of interest.

The determination of isotopic ratios of some elements has been used as a method for the identification of the original sources of the raw materials used in glass, metals and ceramics. (Giussani 2009). We can mention how the ${ }^{87} \mathrm{Sr} /{ }^{86} \mathrm{Sr}$ isotopic ratio has been successfully used for the determination of the flux used (ash or limestone) in the production of Chinese glazes (Ma 2014).

\subsection{Identification of crystalline compounds.}

The most common technique for identification of the crystalline compounds is X-ray Diffraction (XRD). XRD can be performed directly on the surface of the glaze, provided that the surface is flat enough. Typical penetration of the X-rays into the glaze depends on the composition, varying from a few micrometres to tens of micrometres; this may limit the 
identification of compounds which are close to the glaze-ceramic interface. Transmission $\mu$ XRD using synchrotron light has the advantage of accessing different areas of the thin (50-100 $\mu \mathrm{m})$ cross-section of the glaze with micrometric resolution (Figure 4D and 6H) (Pradell 2010). Micro-Raman Spectroscopy has also been profusely used, either over the surface or over a polished cross section of the glaze. It has proved to be a powerful technique for the identification of crystalline compounds either related to the decorations or to the glazes, but also in ascertaining the glazes components if sampling is not accessible (Clark 1998, Colomban 2001, 2004, 2005, 2017a,b, Waal 2007).

9.5 Oxidation and coordination of chromophores. Colour, saturation/whiteness and opacity.

Light absorption in the visible wavelength range (between $380 \mathrm{~nm}$ and $740 \mathrm{~nm}$ ) is responsible for the colour of glass. The absorption is related to the nature of the atoms present and the interaction forces linking them to the glass structure. Therefore, the colour of a glaze is mainly due to the presence of ions, principally those of metal transition elements with their different oxidation states, and different ways in which they are linked to the glaze (coordination). Spectroscopic techniques such as, UV-Vis-NIR (Figure 2), XPS and XANES, EXAFS (Cotte 2010, Pradell 2016, 2018, Wen 2017) are able to identify the oxidation state and coordination of the elements present in the glaze.

Apart from the absorption of light by the glaze components and chromophores, pigment particles are also added to the glazes to impart colour or opacity. Light is reflected at on all interfaces, (air-glaze, glaze-ceramic body) including the interface between the particles and the glaze, where the phenomenon is normally referred to scattering, part of this scattered light is directed back to the surface, increasing the total light reflected, hence the opacity of the glaze. The analysis of the visible range also allows the calculation of the colour coordinates, saturation (whiteness) and lightness (opacity). Although the glazes are essentially colourless and the refractive index is, in a first approach, constant throughout the visible range both near the UV $(200 \mathrm{~nm}-380 \mathrm{~nm})$ and in the NIR (780-2500 nm), the absorption increases. In the UV region, this is because the light has enough energy to extract electrons from the glass or due to the presence of impurities. In the NIR region, it is due to the presence of gases or water and also impurities. Therefore, analysis of the UV and NIR regions helps to determine the presence of small impurities of chromophores that may be hidden in the Vis range due to scattering.

The most accessible and basic spectroscopic technique for the identification of chromophores is UV-Vis-NIR. The visible range is obviously directly responsible for the colour, but the Ultraviolet and Near Infrared ranges are also of great help, in particular when scattering is present in the visible range masking the absorption peaks of the chromophores. The exact 
position of the absorption bands depends not only on the chromophores groups, but also on the nature of the glass components. UV-Vis-NIR spectra of the most common chromophores are shown in Figure 2.

The only requirement for the UV-Vis-NIR analysis is to have a flat surface which fits into the instrument. It is also possible to use portable systems with an optical fibre which leads the light to the area of interest; these are becoming relatively common instruments.

Colour analysis may be performed using a double beam UV-Vis spectrometer equipped with an Ulbricht Sphere (Figure 9I), which detects the total diffused light either by including or excluding the specular reflected light. Using the International Commission on Illumination (CIE), it is possible to determine the so called CIELAB colour model which, given its white point, is device-independent. The colour coordinates are given in terms of a sphere representing lightness $L^{*}\left(0\right.$, black to 100 , diffuse white), $a^{*}\left(+100\right.$ red to -100 green) and $b^{*}(+100$ yellow to -100 blue) (Figure 9K). From these, chromac $c^{*}=\sqrt{a^{* 2}+b^{* 2}}$, colour saturation (contrary to whiteness) $s^{*}=\sqrt{c^{* 2}+L^{* 2}}$, and hue (colour) $h^{*}=\operatorname{atan}\left(\frac{b^{*}}{a^{*}}\right)$ area, are also calculated.

X-ray photoelectron Spectroscopy (XPS) is based on the emission of electrons from a material illuminated by X-rays. The photo-electrons emitted have specific energies which are related to the nature and oxidation state of the elements, and therefore, the method has been used in the determination of the oxidation state of some chromophores and particles present in the glazes. Once again, the only requirement is to have a flat surface. The main limitation is the penetration of the technique which is only a few nanometres. This means that it only provides surface analysis, and if access to the inner areas of the glazes is required, the upper layers must be removed using an ion beam (normally Ar) which in many cases may affect the oxidation state of the chromophores. This is also a non-invasive technique provided that the sample is flat and fits into the measuring chamber.

For the study of surface structures, X-ray absorption spectroscopy (XAS) can be proficiently used. These are synchrotron-based techniques (Cotte 2010, Pradell 2016 and 2018, Wen 2017) where the X-rays are scanned around the element absorption band with enough wavelength resolution to distinguish between different oxidation states and coordination sites (Figure 9I). If the study is restricted to the position of the absorption edge, the technique is called X-ray Absorption Near Edge Structure (XANES). If the spectral range is extended further, the interference between the X-rays scattered in the neighbouring atoms can be analysed, and the valence, nature and distance of the atoms in the first coordination sphere determined with precision; the technique being called Extended X-ray Absorption Fine Structure (EXAFS). The measurements may be performed either in transmission or fluorescent mode. Consequently, glazes can be measured directly over the surface, with the limitations resulting from the penetration depth of the X-rays (typically of a few micrometres), or considering the small size 
of the beam spot (a few hundred nanometres) on polished cross sections of the glazes. This analysis is quantitative and non-invasive. However, in order to access different areas of the glaze, it is necessary to work over the cross section which requires of some sample manipulation.

\subsection{Non-invasive techniques}

In fact, truly non-invasive techniques do not exist, since information can only be obtained if there is an interaction. However, the concept of non-invasiveness is normally associated with not extracting samples for analysis, rather than the lack of interaction. Although, the use of noninvasive techniques is becoming more extensive, they have advantages and disadvantages. The main advantage is the elimination of sample extraction, so that all parts of a large object can be probed without damage to the object, thus obtaining more statistically representative data.

On the other hand, the main limitation is that only surface analytical techniques are possible. Among the problems associated with such methods are:

a) the surfaces geometry normally does not comply with the standards required for quantitative analysis

b) the presence of "windows" in the detectors (thin layers of a metal to that separate the inner parts of the detector from the air) which limit the detection of light elements

c) the need for vacuum in the analytical chamber; and the limitation of the analysis to a few microns below the surface due to the reduced penetration depth of the radiation beam.

Nevertheless, analytical equipment and setups have been modified to be less surface geometry demanding, mainly reducing the size of the area analysed. Also, detector windows can sometimes be removed, larger objects can be included in the analytical chambers, and vacuum requirements can be removed, thus allowing for a new generation of non-invasive analytical techniques. They are particularly important for those situations in which sample extraction is not possible, based on conservation issues and for expensive, whole or unique Museum objects, where non-invasive techniques are the only analytical tool permitted (Bezur 2012). However, surface analysis of a glaze will always be problematical because of the frequent alteration of the glaze surface due to weathering.

In the cases when SEM-EDS and Microprobe cannot be used because they require the removal of a sample, and even LA-ICP-MS might be regarded as destructive, the only option left for the chemical analysis of the glazes is X-ray Fluorescence (XRF). XRF and PIXE detectors can be calibrated, with some limitations mainly with the determination of light elements or due to the penetration depth. As a result of surface alteration, most of the analysis can only be regarded as providing semiquantitative data for major, minor or trace elements (Bezur 2012).

The use of non-invasive techniques is more important in the analysis of porcelain, for obvious reasons, mainly dedicated to identifying the nature of the glassy phase and of the pigments and 
colourants (Pevenage 2014, Giannini 2017, Colomban 2001, 2004, 2017 a,b). We have to highlight the fact that the problems that alteration poses on the analysis of the glazes are drastically reduced for high temperature fired ceramics.

\section{CONCLUSIONS}

A ceramic glaze is a thin glassy layer fused to the surface of a ceramic body by firing. Its study provides information about the chemical composition, microstructure and firing traditions, as well as the decorative style and technique.

A glaze is an open system and the chemical composition changes during firing mainly due to the interaction with the ceramic (interdiffusion of elements between glaze and ceramic body) and the volatilisation of some compounds. The main microstructures found in the glazes are: bubbles, cracks, amorphous and crystalline phases, including undissolved compounds and crystals formed during the firing.

The colours of the glazes are also obtained by the presence/addition of transition metals $(\mathrm{Fe}, \mathrm{Cu}$, $\mathrm{Co}, \mathrm{Mn}$ and $\mathrm{Cr}$ ) in the form of ions (colourants) and/or crystalline compounds. Opacity of glazes could be obtained in multiples forms: by the presence of undissolved particles, neo-formed immiscible small crystallites, bubbles or nano-metric amorphous droplets.

Finally, corrosion microstructures formed due to the use or burial of the glazed object, are also often present. Corrosion involves the leaching of glaze components and incorporation of elements from the environment and, finally, the precipitation of new compounds.

Studying and analysing glazes involve several approaches, depending on the historical question and the possibility of extracting samples. Analysis of the glazes normally requires the use of micro-analytical techniques from selected areas on polished cross-sections.

\section{Acknowledgments}

This chapter was carried out as part of the research conducted on glazes since 1990 by T Pradell and J Molera. We would like to thank Professor MS Tite for his detailed revision of the manuscript, comments and suggestions which soundly improved the text. Long-time financial support has been provided by MINECO (latest project MAT2016-77753-R) and Generalitat de Catalunya (latest project 2017-SGR-00042). 


\section{References}

Allan JW (1973). Abü'l-Qäsim's Treatise on Ceramics, Iran, IX, 111-20

Aloupi-Siotis, E. (2020). Ceramic technology. How to characterise black Fe-based glassceramic coatings. Archaeological and Anthropological Sciences [this topical collection]

Armstrong P (2018). The earliest glazed ceramics in Constantinople: a regional or international phenomenon?. EAA Barcelona 2018 - Glaze production technology in the medieval and postmedieval Mediterranean.

Bao Z, Yuan H, Wen R, Chen K (2015). The fast and direct characterization of blue-and white porcelain glaze from Jingdezhen by laser ablation-inductively coupled plasma mass spectrometry. Anal Methods 7: 5034-5040

Bezur JA, Casadio F (2012). The analysis of porcelain using handheld and portable X-ray fluorescence spectrometers, Chapter 8 in "Handheld XRF" Leuven University Press. Leuven (Belgium) pp. 245-312

Beltrán de Heredia Bercero J (2007). Pisa arcaica i vaixella verda al segle XIII. L'inici de la producció de pisa decorada en verd i manganès a la ciutat de Barcelona. Quarhis-Quaderns d'Arqueologia i História de Barcelona. Època II(3): 138-159.

Biron I, Beauchoux S (2003). Ion beam analysis of Mosan enamels. Meas. Sci. Technol. 14(9): 1564-1578.

Bouquillon A, D'alessandro A, Katona I, Zucchiatti A (2005). PIXE analysis of artistic blue glazes and the use of cobalt pigments in ceramics during the italian renaissance. Int. J.PIXE 15(1): 317-322.

Blake H (1980). The archaic Maiolico of north-central ltaly: Montolcino, Assisi and Tolentino. Faenza LXVI(1-6): 91-152

Brill RH (1979). Chemical studies of Islamic luster glass in Scientific methods in medieval Archaeology, chapter XVI. UCLA Centre for Medieval and Renaissance studies. Contributions IV, ed Berger R, pp. 351-377, Berkeley CA (USA).

Caiger Smith A (1991). Lustre pottery. New Amsterdam Books, New York, EUA. 
Carboni S (2002). The early period, chap. 2 in Glass from Islamic lands: the Al-Sabah collection, Thames and Hudson, New York (USA) pp. 50-137

Chapoulie R, Déléry C, Daniel F, Vendrell-Saz M (2005). Cuerda seca ceramics from alAndalus, Islamic Spain and Portugal $\left(10^{\text {th }}-12^{\text {th }}\right.$ centuries AD): Investigation with SEM-EDX and cathodoluminescence. Archaeometry 47(3): 419-534

Clark RJH, Curri ML (1998). The identification by Raman microscopy and X-ray diffraction of iron-oxide pigments and of the red pigments found on Italian pottery fragments. J Molec Struct 440 (1-3): 105-111.

Coentro S, Mimoso JM, Lima AM, Silva AS, Pais AN, Muralha VSF (2012). Multi-analytical identification of pigments and pigment mixtures used in 17th century Portuguese azulejos. J Eur Ceram Soc 32: 37-48.

Coentro, S, Alvesc, LC, Coll Conesa J, Ferreira T, Mirão J, da Silva RC, Trindade R, Muralha VSF (2020). White on blue: A study on underglaze-decorated ceramic tiles from 15th-16thcentury Valencian and Sevillian productions. J Archaeol Sci: Rep 30: 102254

Colomban P, Treppoz F (2001). Identification and differentiation of ancient and modern European porcelains by Raman macro- and micro-spectroscopy. J Raman Spect 32 (2): 93-102.

Colomban P, Robert I, Roche C, Sagon G, Milande V (2004). Identification des porcelaines "tendres" du 18ème siècle par spectroscopie Raman: Saint-Cloud, Chantilly, Mennecy et Vincennes/Sèvres. Rev d'Archéométrie 28: 153-167.

Colomban P, Paulsen O (2005). Non-destructive determination of the structure and composition of glazes by Raman spectroscopy. J Amer Ceram Soc 88 (2): 390-395.

Colomban P, Zhang Y, Zhao B (2017a). Non-invasive Raman analyses of Chinese huafalang and related porcelain wares. Searching for evidence for innovative pigment technologies. Ceram Intern. 43: 12079-12088

Colomban P, Ambrosi F, Ngoa A, Lua T, Feng X, Chen S, Choi C (2017b). Comparative analysis of wucai Chinese porcelains using mobile and fixed Raman microspectrometers. Ceram Intern. 43: 14244-14256

Cotte M, Susini J, Dik J, Janssens K (2010). Synchrotron-based X-ray Absorption spectroscopy for art conservation: Looking back and looking forward. Acc Chem Res 43(6): 705-714. 
de Lapérouse, JF (2020). Ceramic musealisation: How ceramics are conserved and the implications for research. Archaeological and Anthropological Sciences [this topical collection]

de Waal D (2007). Raman analysis of underglaze pigments on porcelain art. J Raman Spec 38 (7): 956-957.

Déléry C (2006). Dynamiques économiques, sociales et culturelles d'al-Andalus à partir d'une étude de la céramique de cuerda seca (seconde moitié du Xe siècle - première moitié du XIIIe siècle), Thése Toulouse 2.

Di Febo R, Molera J, Pradell T, Vallcorba O, Melgarejo JC, Capelli C (2017). Thin-section petrography and SR-microXRD for the identification of micro-crystallites in the brown decorations of ceramic lead glazes. Eur J Min 29(5): 861-870.

Di Febo R, Molera J, Pradell T, Vallcorba O, Capelli C (2017b). Technological implications of neo-formed hematite crystals in ceramic lead glazes. STAR 3(2): 366-375

Di Febo R, Molera J, Pradell T, Melgarejo JC, Madrenas J, Vallcorba O (2018). The production of a lead glaze with galena: Thermal transformations in the PbS-SiO2 system. J Amer Ceram Soc. 101: 2119-2129.

Eramo, G. (2020). Ceramic technology. How to recognize clay processing. Archaeological and Anthropological Sciences [this topical collection]

Fehérvári G (2000) Ceramics of the Islamic World in the Tareq Rajab Museum Chapter 3: the Fatimid period in Egypt and North Africa (late tenth to twelfth centuries) London-New York pp. $65-77$

Freestone IC (2002). The relationship between enamelling on ceramics and on glass in the Islamic world. Archaeometry 44(2): 251-255

Galli, A., Sibilia, E., Martini, M. (2020). Ceramic chronology by luminescence dating. How and when it is possible to date ceramic artefacts. Archaeological and Anthropological Sciences [this topical collection]

Giannini R, Freestone IC, Shortland AJ (2017). European cobalt sources identified in the production of Chinese famille rose porcelain. J Archaeol Sci 80: 27-36 
Giussani B, Monticelli D, Rampazzi L (2009). Role of laser ablation-inductively coupled plasma-mass spectrometry in cultural heritage research: A review. Anal Chim Acta 635: 6-21

Gliozzo, E. (2020a) Ceramics investigation. Research questions and sampling criteria. Archaeological and Anthropological Sciences [this topical collection]

Gliozzo, E. (2020b) Ceramic technology. How to reconstruct the firing process. Archaeological and Anthropological Sciences [this topical collection]

Gratuze B, Blet-Lemarquand J, Barrandon JN (2001). Mass Spectrometry with laser sampling: a new tool to characterize Archaeological materials. J Radioanal Nucl Chem 247: 645-656.

Gualtieri, S. (2020). Ceramic raw materials. How to establish the technological suitability of a raw material. Archaeological and Anthropological Sciences [this topical collection]

Guo YY (1987). Raw materials for making porcelain and the characteristics of porcelain wares in North and South China in ancient times. Archaeometry 29: 3-19.

Hein, A., Kilikoglou, V. (2020). Ceramic raw materials. How to recognize them and locate the supply basins. Chemistry. Archaeological and Anthropological Sciences [this topical collection]

Henderson J, Wood N, Tregear M (1989). The technology of sixteenth and seventeenth Chinese cloisonné enamels. Archaeometry 31(2): 133-146

Henderson, J., Ma, H., Cui, J., Ma, R., Xiao, H., Liu, Y-J. (2020). Isotopic investigations of Chinese ceramics. Archaeological and Anthropological Sciences [this topical collection]

Henshaw CM (2010). Early Islamic ceramics and glazes of Akhsiket, Uzbekistan. PhD. UCL

Hill DV, Speakman RJ and Glascock MD (2004). Chemical and mineralogical characterization of Sasanian and early Islamic glazed ceramics from the Deh Luran plain, southwestern Iran. Archaeometry 46(4): 585-605

Holakooei P, LF de Lapérouse, Caròc F, Röhrs S, Franke U, Müller-Wiener M, Reiche I (2019). Non-invasive scientific studies on the provenance and technology of early Islamic ceramics from Afrasiyab and Nishapur. J Archaeol Sci: Rep 24:759-772

Hou J, Pradell T, Li Y, Miao J (2018). Jun ware glazes: Chemistry, nanostructure and optical properties. J Eur Ceram Soc 38 4290-4302. 
Ionescu, C., Hoeck, V. (2020). Ceramic technology. How to investigate surface finishing. Archaeological and Anthropological Sciences [this topical collection]

Kleinmann B (1986). History and development of early Islamic pottery galzes, in Olin JS and Blackman MJ (eds) Proceedings of the 24th Archaeometry Symposium 73-84, Washington DC: Smithsonian Institution Press

Kim JY, No HG, Jeon AY, Kim US, Pee JH, Cho WS, Kim KJ, Kim CM, Kim CS (2011). Mössbauer spectroscopic and chromaticity analysis on colorative mechanism of celadon glaze, Ceram Int. 37: 3389-3395.

Kingery WD, Vandiver PB (1983). Song Dynasty Jun (Chün) ware glazes, Am Ceram.Soc Bull. 62(11): 1269-1279 then 1279-1282.

Kingery WD, Vandiver PB (1983b). Spinodal decomposition in a K20-A1203-Ca0-Si02 glass. Com Amer Ceram Soc. C-171-172.

Kingery WD, Vandiver PB (1986). Ceramic Masterpieces: Art, Structure and Technology, Free Press (New York, USA)

Kingery WD, Vandiver PB (1986b). The eighteenth-century change in technology and style from the famille-verte palette to the famille-rose palette. In: Technology and Style: Proceedings of a Symposium on Ceramic History and Archaeology at the 87th Annual Meeting of the American Ceramic Society, 6 May 1985, Cincinnati, pp. 363-381.

Kühnel E (1934). Die Abbasidischen Lüsterfayencen, Ars Islamica I.

Lenting C, Plümper O, Kilburn M, Guagliardo P, Klinkenberg M, Geisler T (2018). Towards a unifying mechanistic model for silicate glass corrosion. NPJ Mater Degrad. 2(1): 28

Li B (2010). Red-and-green enamelled ceramics from the Jin and Yuan dynasties: Recent discoveries, cultural significance and associations with Jingdezhen porcelains, The Oriental Ceramic Society Newsletter 18: 11-14

Li W, Li J, Deng Z, Wu J, Guo J (2005). Study on Ru ware glaze of the Northern Song dynasty: One of the earliest crystalline-phase separated glazes in ancient China. Ceram Int 31: 487-494

Ma H, Henderson J, Evans J (2014). The exploration of Sr isotopic analysis applied to Chinese glazes: part one. J Archaeol Sci. 50: 551-558 
Maggetti M, D'Albis A (2017). Phase and compositional analysis of a Sèvres soft paste porcelain plate from 1781, with a review of early porcelain techniques. Eur J Mineral 29: 347367

Maritan, L. (2020). Ceramic abandonment. How to recognise post-depositional transformations. Archaeological and Anthropological Sciences [this topical collection]

Mason RB, Tite MS (1994). The beginnings of Islamic stonepaste technology. Archaeometry. 36: 77-91

Mason RB (1997). Early Mediaeval Iraqi lustre-painted and associated wares: typology in a multidisciplinary study. Iraq, LIX, 1: 47

Mason RB, Tite MS, Paynter S, Salter C (2001). Advances in polychrome ceramics in the Islamic world of the 12th century AD. Archaeometry. 43(2): 191-209

Matin M (2018). On the origins of tin-opacified ceramic glazes: New evidence from early Islamic Egypt, the Levant, Mesopotamia, Iran, and Central Asia, J Archaeol Sci. 97: 42-66

McCarthy BE (1996). Microstructural and compositional studies of the technology and durability of ceramic glazes from Nippur, Itaq, ca 250BC to $1450 \mathrm{AD}, \mathrm{PhD}$ dissertation, Baltimore: John Hopkins University

Melcher M, Schreiner M (2001). Evaluation procedure for leaching studies on naturally weathered potash-lime-silica glasses with medieval composition by scanning electron microscopy, J Non-Crystall Sol. 351(14-15): 1210-1225.

Miao J, Yang B, Mu D (2010). Identification and differentiation of opaque Chinese overglaze yellow enamels by Raman spectroscopy and supporting techniques. Archaeometry. 52(1): 146155

Molera J, Pradell T, Martinez-Manent S, Vendrell-Saz M (1993). The growth of sanidine crystals in the lead glazes of Hispano-Moresque pottery. Appl Clay Sci. 7: 483-491

Molera J, Pradell T, Vendrell-Saz M (1998). The colours of Ca-rich ceramic pastes: origin and characterization. Appl Clay Sci. 13: 187-202

Molera J, Pradell T, Salvado N, Vendrell-Saz M (1999). Evidence of tin oxide recrystallization in opacified lead glazes. J Amer Ceram Soc. 82: 2871-2875. 
Molera J, Pradell T, Salvado N, Vendrell-Saz M (2001). Interactions between Clay Bodies and Lead Glazes. J Am Ceram Soc. 84(5): 1120-28

Molera J, Bayés C, Roura P, Crespo D, Pradell T (2007). Key parameters in the production of medieval lustre colors and shines. J Am Ceram Soc. 90(7): 2245-2254

Molera J, Pradell T, Salvado N, Vendrell-Saz M (2009). Lead frits in Islamic and HispanoMoresque glazed productions, in From Mine to Microscope ed Shortland Advances in the study of Ancient mateirals. Freestone I and Rehren T. Ed. Chapter 1, pp. 1-11. Oxbow books.

Molera J, Coll J, Labrador A, Pradell T (2013). Manganese brown decorations in 10th to 18th century Spanish tin glazed ceramics. App clay sci. 82: 86-90

Molera J, Martínez Ferreras V, Fusaro A, Gurt Esparraguera JM, Gaudenzi M, Pidaev SR, Pradell T (2020). Islamic glazed wares from ancient Termez (southern Uzbekistan). Raw materials and techniques. J Archaeol Sci Rep. 29: 102169

Molina G, Tite MS, Molera J, Climent-Font A, Pradell T (2014). Technology of production of polychrome lustre. J Eur Ceram Soc. 34 2563-2574

Montana, G. (2020). Ceramic raw materials. How to recognize them and locate the supply basins. Mineralogy, Petrography. Archaeological and Anthropological Sciences [this topical collection]

Moreno MJ (1987). La cerámica de cuerda seca peninsular: orígen y dispersión. Actas del II Congreso de Arqueologia Medieval Española. Madrid. pp 33-42

Northedge A (2001). Thoughts on the introduction of polychrome glazed pottery in the Middle East”, in: Villeneuve E; Watson PM (eds), La céramique Byzantine et proto-islamique en SyrieJordanie (IVe-VIIIe siècles apr. JC), Beirut (IFAPO), 207-214.

O'Kane B (2011). Tiles of many hues in "And diverse are their Hues: Color in Islamic Art and Culture", ed. Bloom JM and Blair S. Chapter 6. Appendix by Tite MS and Salter C (Yale University Press)

Pace M, Bianco Prevot A, Mirti P, Venco Ricciard R (2008). The Technology of production of Sasanian glazed pottery from Veh Ardasir (Central Iraq). Archaeometry. 50 591-605 
Padeletti G, Fermo P (2004). Production of gold and ruby-red lustres in Gubbio (Umbria, Italy) during the Renaissance period. Appl Phys A, 79(2): 241-24

Palamara E, Zacharias N, Xanthopoulou M, Kasztovszky Zs, Kovács I, Palles P, Kamitsos EI (2016). Technology issues of Byzantine glazed pottery from Corinth, Greece. Microchem J 129:137-150

Papageorgiou, I. (2020). Ceramic investigation. How to perform statistical analyses. Archaeological and Anthropological Sciences [this topical collection]

Paynter S (2001). The development of vitreous materials in the ancient Near East and Egypt, $\mathrm{PhD}$ thesis, RLAHA, Oxford University

Paynter S, Okyar F, Wolf S, Tite MS (2004). The production technology of Iznik pottery-A Reassessment. Archaeometry, 46(3): 421-437

Pérez-Arantegui J, Soto M and Castillo JR (1999). Examination of the "cuerda seca" decoration technique on Islamic ceramics from al-Andalus. J Archaeol Sci. 26: 935-941

Pérez-Arantegui J, Molera J, Larrea A, Pradell T, Vendrell-Saz M et al (2001). Lustre Pottery from the Thirteenth Century to the Sixteenth Century: A Nanostructured Thin Metallic Film. J. Am Ceram Soc. 84(2) 442-446

Porter V, Watson O (1987). Part II: Tell Minis' wares. Syrian and Iran, three studies in medieval ceramics. Oxford Studies in Islamic Art, IV. Oxford University Press, Oxford (UK), pp. 175248.

Pradell T, Molera J, Roque J, Smith AD, Crespo D, Pantos E, Vendrell M (2005). IonicExchange Mechanism in the Formation of Medieval Lustre Decorations. J Amer Ceram Soc. 88(5): 1281-1289

Pradell T, Molera J, Salvadó N, Labrador A (2010). Synchrotron radiation micro-XRD in the study of glaze technology. Appl Phys A 99: 407-417

Pradell T, Pavlov R, Gutiérrez PC, Climent-Font A. Molera J (2012). Composition, nanostructure and optical properties of silver and silver-copper lustres. J App Phys 112(5): 054307 
Pradell T, Molera J, Molina G, Pla, J, Labrador A (2013). The use of micro-XRD for the study of glaze color decorations. Appl Phys A 111: 121-127

Pradell T (2016). Lustre and Nanostructures-Ancient Technologies Revisited In: Dillmann P, Bellot Gurlet L, Nenner I (Ed.), "Nanoscience and Cultural Heritage", Chap 1, Atlantis Pres. Springer series in Physical Chemistry. http://www.springer.com/us/book/9789462391970

Pradell T, Fernandes R, Molina G, Smith AD, Molera J, Climent-Font A (2018). Technology of production of Syrian lustre (11th to 13th century). J Eur Ceram Soc 38(7): 2716-2727

Pradell, T., Molera, J. (2020). Ceramic technology. How to characterise ceramic glazes. Archaeological and Anthropological Sciences [this topical collection]

Patitucci Uggeri S (1985). La protomaiolica del Mediterraneo orientale in rapporto ai centri di produzione Italiani. CorsiRav 32: 337-402

Quinn PS (2013). Ceramic Petrography. The interpretation of Archaeological Pottery \& related artefacts in thin section. Archaeopress, Oxford. pp. 251

Reedy CL (2016). Petrographic and image analysis of thin sections of classic wares of the Song dynasty. Proceedings of the International Symposium on Science and Technology of five great wares of the Song dynasty. N Shi and J Miao ed. Sciencep. (Beijing) pp. 381-390

Rehren TH, Yin M (2012). Melt formation in lime-rich proto-porcelain glazes. J Archaeol Sci. 39: $2969-2983$

REMAI (2012). Proceedings of the 1st International Conference of the European Network of Museums of Islamic Art, Museo de la Alhambra, V\&A and Musée du Louvre

Rodziewicz M (1983). Egyptian glazed pottery of the eighth to ninth centuries. Bull Soc Archéol Copte. 25: 73-75

Rogers, P (1992). Ash glazes. A \& C Black, London and University of Pennsylvania Press, Philadelphia.

Rosser-Owen M (2010). Islamic arts from Spain, V\&A Publishing, London

Salinas E, Pradell T (2018). The transition from lead transparent to tin-opacified glaze productions in the western Islamic lands: al-Andalus, c. 875-929 CE. J Archaeological Sci. 94: $1-11$ 
Salinas E, Pradell T, Molera J (2019). Glaze production at an early Islamic workshop in alAndalus. Archaeol Anthropol Sci. 11(5) 2201-2213

Salinas E, Pradell T, Matin M, Tite MS (2019b). From tin- to antimony-based yellow opacifiers in the early Islamic Egyptian glazes: Regional influences and ruling dynasties, J Archaeol Sci Rep. 26: 101923

Scanlon GT (1998). Slip-Painted Early Lead-Glazed Wares from Fustat: A Dilemma of Nomenclature in: Gayraud, RP (ed.). Colloque International d'Archéologie Islamique 3-7 février 1993, IFAO, Cairo, 21-53.

Sciau, Ph, Sanchez, C., Gliozzo, E. (2020). Ceramic technology. How to characterise terra sigillata ware. Archaeological and Anthropological Sciences [this topical collection]

Shelby JE (2005). Introduction to Glass Science and Technology. Royal Society of Chemistry. Second edition.

Soustiel J (1985). La céramique Islamique. Fribourg: Office du libre

Taxel I (2014). Luxury and common wares: socio-economic aspects of the distribution of glazed pottery in early Islamic Palestine. Levant. 46(1): 118-139.

Thér, R. (2020). Ceramic technology. How to reconstruct and describe pottery-forming practices. Archaeological and Anthropological Sciences [this topical collection]

Tichane R (1978). Those Celadon Blues, Institute for Glaze Research, New York State, US.

Tite MS, Freestone IC, Bimson M (1983). Egyptian faience: an investigation of the methods of production. Archaeometry. 25(1): 17-27

Fite MS, Freestone IC, Bimson I (1984). A technologieal study of Chinese porcelain of the Yuan dynasty. Arehaeometry. 26(2) 139-154

Tite MS, Freestone IC, Mason R, Molera J, Vendrell-Saz M, Wood N (1998). Lead glazes in antiquity-methods of production and reasons for use, Archaeometry. 40(2) 241-260

Tite MS, Pradell T, Shortland A (2008). Discovery, production and use of tin-based opacifiers in glasses, enamels and glazes from the Late Iron Age onwards: a reassessment, Archaeometry. 50: $67-84$ 
Tite MS (2009). The production technology of Italian maiolica: a reassessment J Archaeol Sci. 36: $2065-2080$

Tite MS, Watson O, Pradell T, Matin M, Molina G, Domoney K, Bouquillon A (2015). Revisiting the beginnings of tin-opacified Islamic glazes. J Archaeol Sci. 57: 80-91

Tite MS, Shortland AJ, Schibille N, Degryse P (2016). New data on the soda flux used in the production of Iznik glazes and Byzantine glazes. Archaeometry. 58(1): 57-66

Ting C, Lichtenberger A, Raja R (2019). The technology and production of glazed ceramics from middle Islamic Jerash, Jordan. Archaeometry. 21(6): 1296-1312

Van Pevenage J, Lauwers D, Herremans D, Verhaeven E, Vekemans B, De Clercq W, Vincze L, Moens L, Vandenabeele P (2014). A combined spectroscopic study on Chinese porcelain containing ruan-cai colours. Anal. Methods. 6: 387

Vandiver PB (1982). Technological change in Egyptian faience. In Archaeological Ceramics. (eds. Olin JS and Franklin AD) Washington DC: Smithsonian Institution Press, pp. 167-179

Vandiver PB (1983). Appendix A: The manufacture of faience. In Ancient Egyptian faience. (Karczmarczyk A and Hedges REM). Warminster: Aris and Phillips, pp. A1-A137

Vandiver PB (2016). Variability of Song dynasty green glaze technology using microstructure, microcomposition and thermal history to compare Yaozhou, Jun, Ru, Longquan, Guan and Korean Koryo dynasty materials and practices. Proceedings of the International Synposium on Science and Technology of five great wares of the Song dynasty. N Shi and J Miao ed. Sciencep. (Beijing) pp. 391-432

Vendrell-Saz M, Molera J, Tite M (2000). Optical properties of tin-opacified glazes. Archaeometry. 42: 325-340.

Viti C, Borgia I, Brunetti B, Sgamellotti A, Mellini M (2003). Microtexture and microchemistry of glaze and pigments in Italian Renaissance pottery from Gubbio and Deruta, J Cult Herit 4(3): 199-210

Vogel W (1992). Glass chemistry, Springer Verlag, Berlin.

Vroom J (2006). Some Byzantine pottery finds from Laman-Kalehöyuk: A first observation, AAS XV: 163-169 
S.Y. Waksman, A. Bouquillon, N. Cantin, I. Katona, The first Byzantine "Glazed White Wares" in the early medieval technological context, in S.Y. Waksman (éd.), Archaeometric and Archaeological Approaches to Ceramics, BAR International Series S1691, 129-135 (2007).

S.Y. Waksman, A. Bouquillon, N. Cantin, I. Katona, Approche archéométrique des premières "Byzantine Glazed White Ware" et de productions glaçurées romaines et romaines tardives, Rei Cretariae Romanae Fautorum Acta 40, 531-536 (2008).

Waksman Y, Capelli C, Pradell T, Molera J (2014). The ways of the lustre: Looking for the Tunisian connection in Craft and science: International perspectives on archaeological ceramics, ed. Martinón-Torres M. UCL Qatar Series in Archaeology and Cultural Heritage, 1 Doha, Qatar, Bloomsbury Qatar Foundation, pp. 109-116

Waksman SY, Burlot J, Böhlendorf-Arslan B, Vroom J (2017). Moulded ware production in the Early Turkish/Beylik period in western Anatolia: A case study from Ephesus and Miletus. J Archaeol Sci Rep. 16: 665-675

Walton MS (2004). A materials chemistry investigation of Archaeological lead glazes, $\mathrm{PhD}$ thesis, Oxford University.

Walton MS and Tite MS (2010) Production technology of Roman lead-glazed pottery and its continuance into late Antiquity. Archaeometry. 52(5): 733 - 759

Watson O (1985). Persian lustre ware, Faber and Faber, London (UK)

Watson O (2014). Revisiting Samarra: the Rise of Islamic Glazed Pottery, Beiträge zur Islamischen Kunst und Archäologie 4: 123-142

Wen R, Zhang, Y Wang D, Wang L (2017). The compositional characterization and painting technique of Chinese red and white porcelain by EDXRF and SR-mXRF mapping analysis. Anal Meth. 9: 4380-4386

Weyl WA (1951, reprint 2016). Coloured glasses, Society of Glass Technology, Sheffield

Whitcomb D (1989). Coptic glazed ceramics from the excavations at Aqaba. Jordan J Am Res Centre Egypt. 26: 167-182.

Wood S, Blachere JR (1978). Corrosion of Lead Glasses in Acid Media: I, Leaching Kinetics. J Amer Ceram Soc. 61(7-8):87-292. 
Wood N (1999). Chinese Glazes: Their Origins, Chemistry and Recreation.A\&C Black, London, UK.

Wood N (2013). Some Mysteries of Jun Ware Manufacture, in: Junyao. Eskenazi, London, UK, pp.17-28.

Wood N, Li H (2015). A study of the techniques used to make Laohudong Guan ware in china in the southern Song dynasty. Archaeometry. 57(4): 617-635

Yianyi G (1987). Raw materials for making porcelain and the characteristics of porcelain wares in north and south China in ancient times. Archaeometry. 29(1): 3-19

Yin M, Rehren Th, Zheng JM (2011). The earliest high-fired glazed ceramics in China: the composition of the proto-porcelain from Zhejiang during the Shang and Zhou periods (c. 1700221 BC). J Archaeol Sci. 38: 2352-2365.

Zhu T, Ding X, Kusimba CM, Feng Z (2015). Using laser ablation inductively coupled plasma mass spectroscopy (LA-ICP-MS) to determine the provenance of the cobalt pigment of Qinghua porcelain from Jingdezhen in Yuan Dynasty of China (1271-1368AD). Ceram Int. 41: 98789884. 


\section{Figure captions}

Figure 1. Glaze microstructures. (A) transparent high lead glaze with lead feldspar crystallites grown at the interface (MAX22, $9^{\text {th }}$ century, Córdoba, Córdoba Emirate); (B) sodalime glaze with bubbles and undissolved quartz grains (P624, polychrome lustre, $9^{\text {th }}$ century, Iraq, Abbasid caliphate); (C) tin glaze with brown and green underglaze decoration (SOL4, $13^{\text {th }}$ century, Barcelona); (D) lead-alkali glaze with bubbles, undissolved quartz grains and pyroxenes grown in the glaze and at the glaze-ceramic interface (P717), polychrome lustre, $9^{\text {th }}$ century, Iraq, Abbasid caliphate).

Figure 2. Glaze colourants. UV-VIS-NIR spectra of the most common colourants.

Figure 3. Opaque glazes. a SEM-BSE image of quartz and feldspar grains in a lead glaze (SBG10, over-glaze cobalt blue decoration, Barcelona, $17^{\text {th }}$ century), b bright field OM image of bubbles in a borosilicate glaze (modern); SEM-BSE images of c small crystals of $\mathrm{SnO}_{2}$ in a lead glaze (P10312, $12^{\text {th }}$ century, Iran) and $\mathbf{d ~} \mathrm{SnO}_{2}$ crystals precipitated into the interface in an alkali glaze (BO2E, modern).

Figure 4. Glaze alterations. (A) glaze corrosion along the surface and also around bubbles and undissolved particles and along cracks and precipitation of lead carbonates inside the bubbles and the cracks (UE9A, blue and lustre $14^{\text {th }}$ century, Cártama, Málaga); (B) glaze corrosion on the surface and along the interface, deposition of soil cemented by the precipitation of lead carbonate and lead-calcium phosphate (MZ2, lead stannate yellow glaze with green decoration, late $10^{\text {th }}$ century, Medina Azahara, Córdoba caliphate); (C) Corrosion along cracks, bubbles and, interface and precipitation of lead carbonates (PH18, polychrome transparent high lead glazed ware, late $9^{\text {th }}$ century, Córdoba caliphate); (D) $\mu$-XRD patterns showing the presence of lead-calcium carbonate and phosphate obtained from the altered areas of a tin glaze.

Figure 5. Nanostructures in Jun ware glazes (JS76, Zhiyaochang kiln). (A) surface appearance (B) cross section Dark Field OM image showing the dark and light blue glazes and the brown glaze at the glaze-ceramic interface; (C) elemental profile across the cross section; FE-SEM images from FIB polished areas showing the glass nanostructures present in the (D) light blue (E) dark blue and (F) brown glazes, and of a (G) Ca-Na feldspar growing at the interface; $(\mathrm{H})$ size distribution of the droplets in the dark blue glaze.

Figure 6. Decorative techniques. (A) side-by-side manganese brown and white tin glazes (ALX65, 10 $0^{\text {th }}$ century, Abbasid, Egypt); (B) side-by-side yellow and green over a white glaze (ALX135, late $10^{\text {th }}-11^{\text {th }}$ century, Fatimid, Egypt); (C) Stereomicroscope and (D) SEM-BSE images of a brown glaze applied over a white glaze (SN63, 10 ${ }^{\text {th }}$ century, San Nicolás, Murcia, Córdoba caliphate, al-Andalus); (E) Stereomicroscope (F) SEM-BSE and (G) Bright Field OM images and $(\mathrm{H}) \mu$-XRD pattern from a cobalt blue under-glaze decoration (SBG20, $16^{\text {th }}$ 
century, Barcelona) showing the presence of lead-calcium arsenate crystallites associated to the blue pigment.

Figure 7. Glazed slip wares. From top to bottom Transmission, Dark Field OM and SEMBSE images from (A), (B) and (C) lead glazed sgrafiatto slipped ware (TA7, $9^{\text {th }}-11^{\text {th }}$ century, Termez, Uzbekistan), (D), (E) and (F) red underglaze decoration in a lead glazed slipped ware (TA9, $9^{\text {th }}-11^{\text {th }}$ century, Termez, Uzbekistan) and $(\mathrm{G}),(\mathrm{H})$ and (I) alkali glazed slipped ware (TS3, $12^{\text {th }}-13^{\text {th }}$ century, Termez, Uzbekistan). K-Pb feldspars and of diopsides are formed at the slip-glaze and ceramic-glaze interface respectively in the sgraffiatto ware. Larger quartz particles are present in the alkali glazed slipped ware

Figure 8. The Enamel. (A) SEM-BSE image from a yellow high lead glaze enamel over white alkali-lime glazed porcelain (EHT12, 1506-1521 Zhengde, Ming dynasty, China) (B) SEM-BSE and elemental profile obtained by SEM-EDX across the yellow-white glazes interface where feldspars are formed. (C) large $\mathrm{K}-\mathrm{Pb}$ feldspars formed at the yellow high lead glaze-porcelain interface (EHT5, Xuantong, 1909-1912, Qing dynasty)

Figure 9. The Lustre. Stereomicroscope images of (A) yellow and red polychrome (IV163, $9^{\text {th }}$ century, Abbasid caliphate, Iraq), (B) coppery red (SAL11, 15 ${ }^{\text {th }}$ century, Barcelona), (C) green, amber and brown polychrome (p56, $9^{\text {th }}$ century, Abbasid caliphate, Iraq), (D) green monochrome (p37, $10^{\text {th }}$ century, Abbasid caliphate, Iraq), (E) brown ( $115,11^{\text {th }}-12^{\text {th }}$ century, Fatimid caliphate, Egypt) and (F) yellow (c1288, second half $13^{\text {th }}$ century, Syria). FE-SEM of FIB polished cross section of a $(G)$ copper red (p717, $9^{\text {th }}$ century, Abbasid caliphate, Iraq) and (H) silver yellow (c1295, second half $13^{\text {th }}$ century, Syria) lustre. (I) Cu k- $\alpha$ XANES spectra from the yellow and red areas (IV163, $9^{\text {th }}$ century, Abbasid caliphate, Iraq) showing that copper is more oxidised in the yellow area. (J) UV-VIS spectra and (K) CIE colour coordinates of red, yellow, brown and green lustres.

Figure 10. Optical Microscopy imaging methods. (A) and (B) Transmission, (C) and (D) XPL Reflection and (E) and (F) PPL Reflection from a manganese brown decoration applied over a quartz-rich slip (TS8, $16^{\text {th }}-17^{\text {th }}$ century, Termez, Uzbekistan). The different modes help to visualize the crystallites formed from the reaction between the manganese pigment particles and the glaze. 


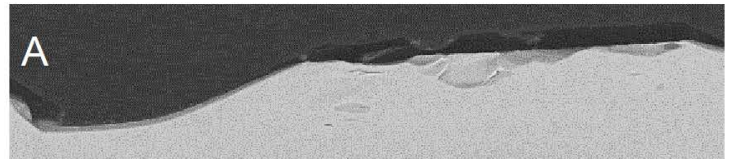

Amorphous phase
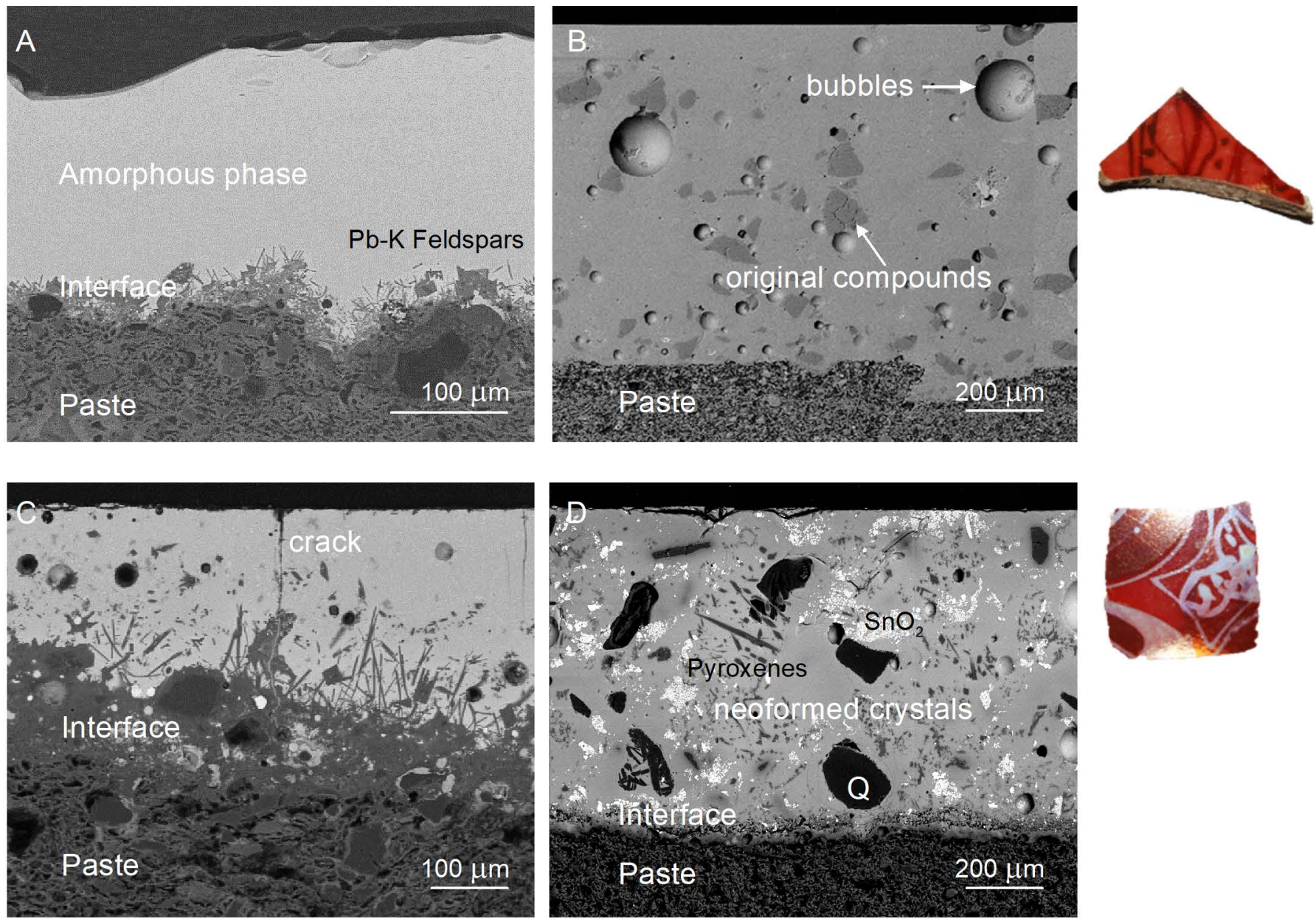


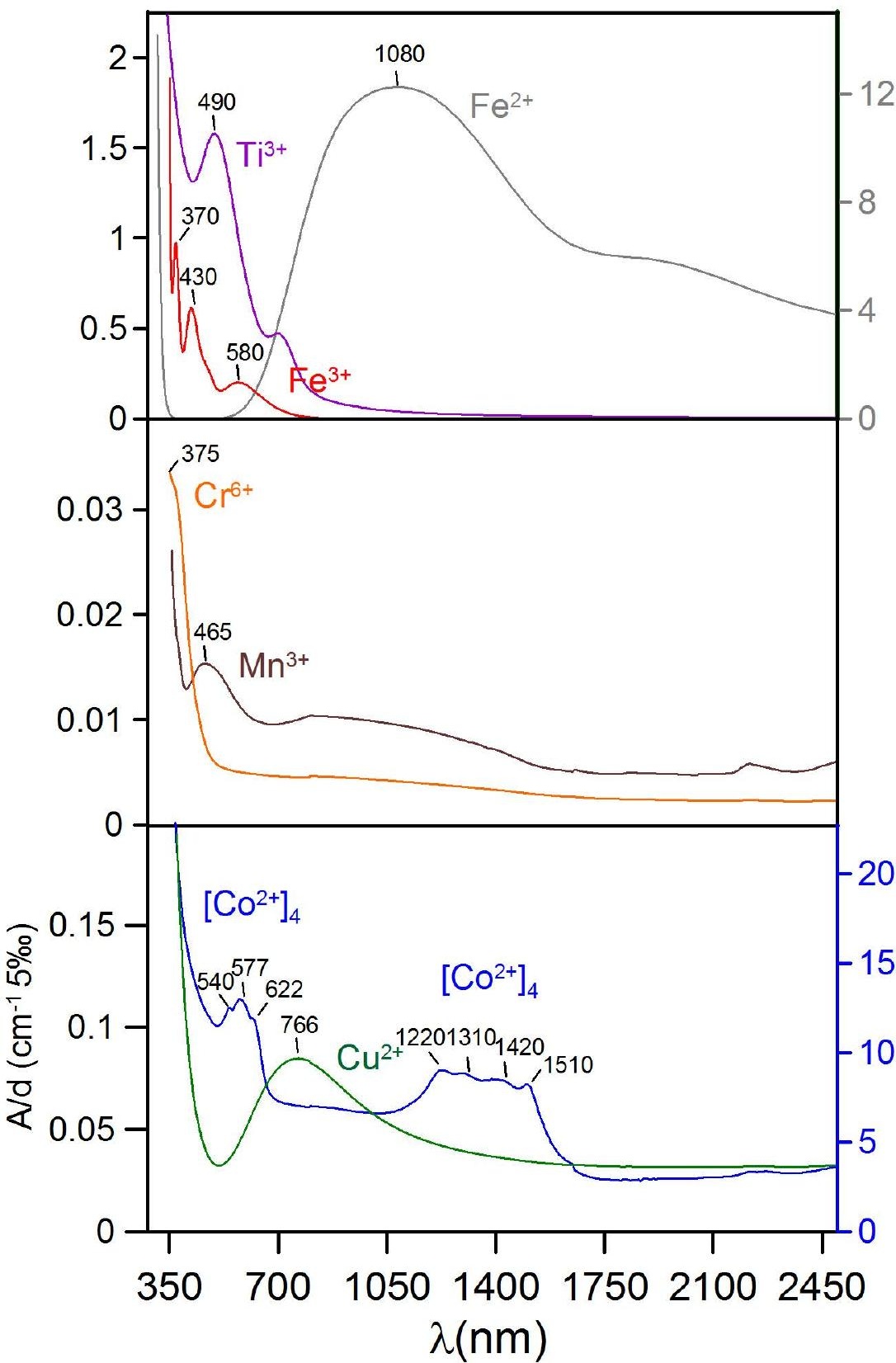




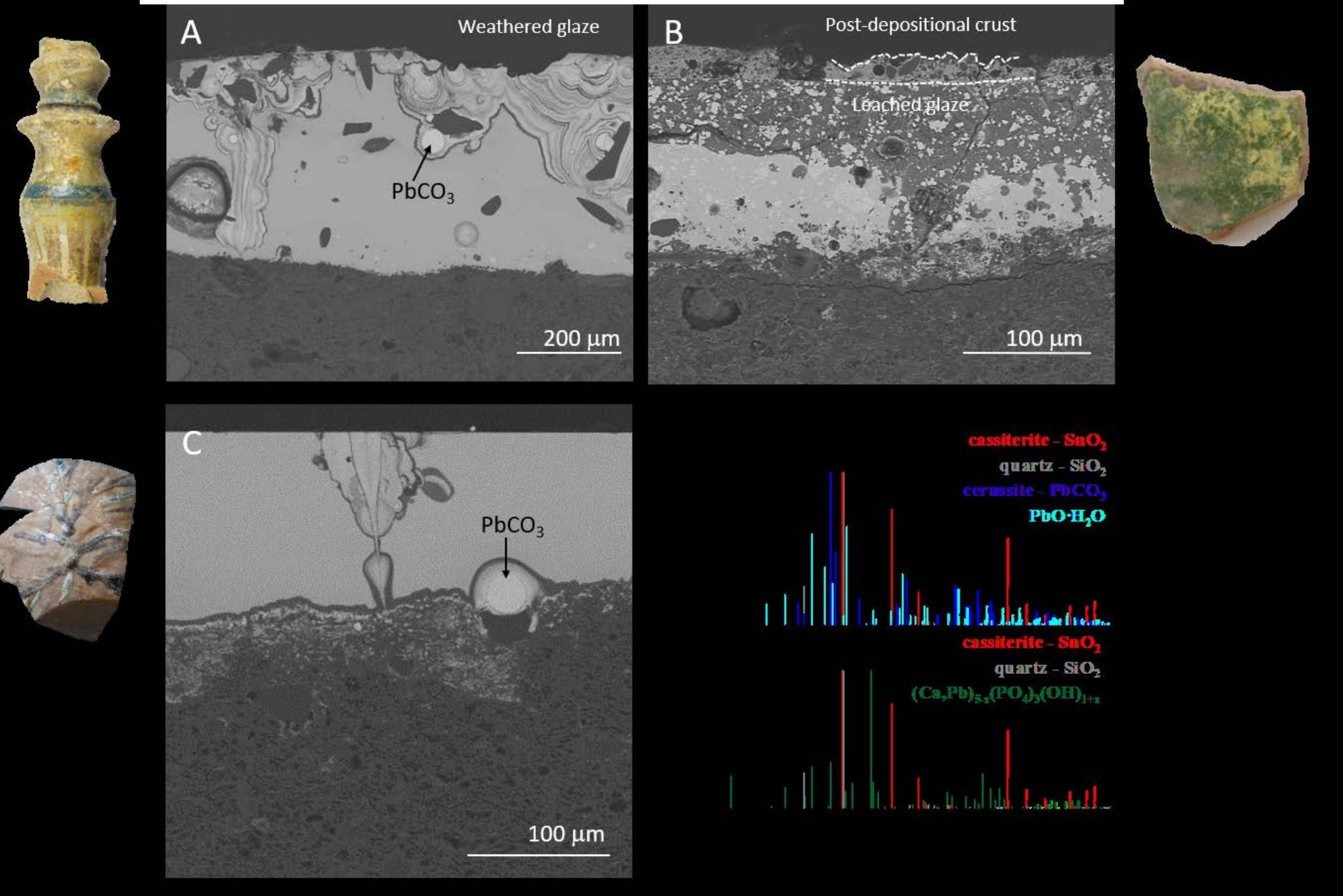




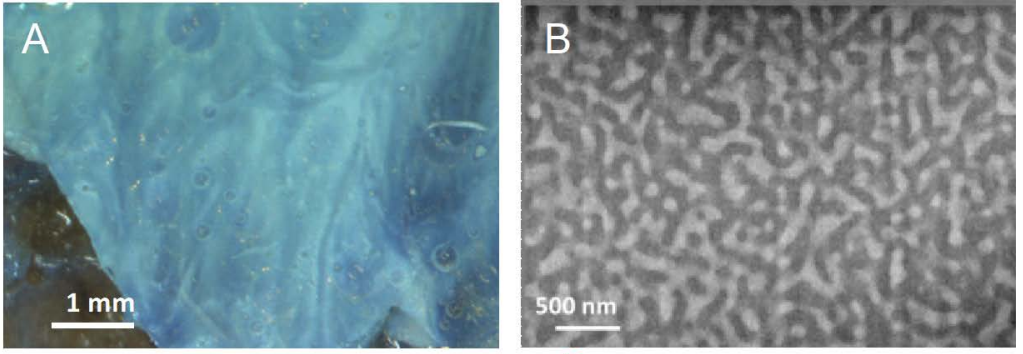

C
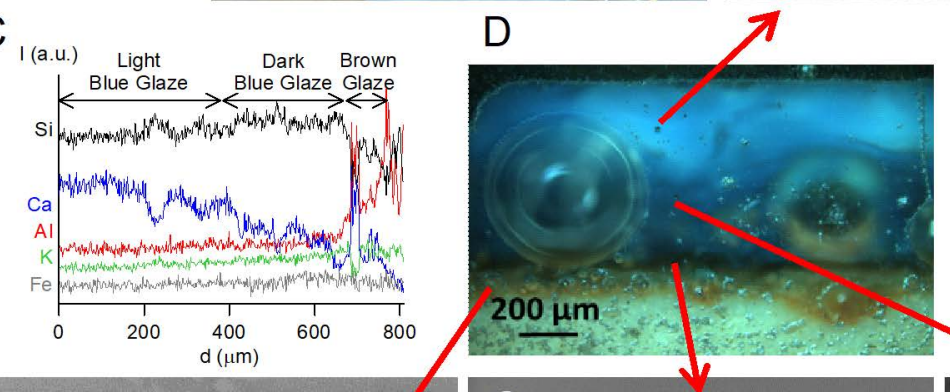

E

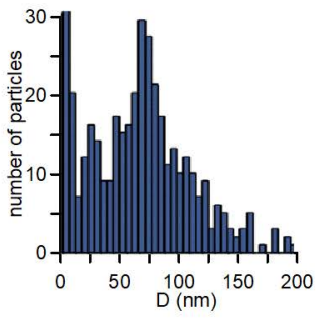

F

G

H 

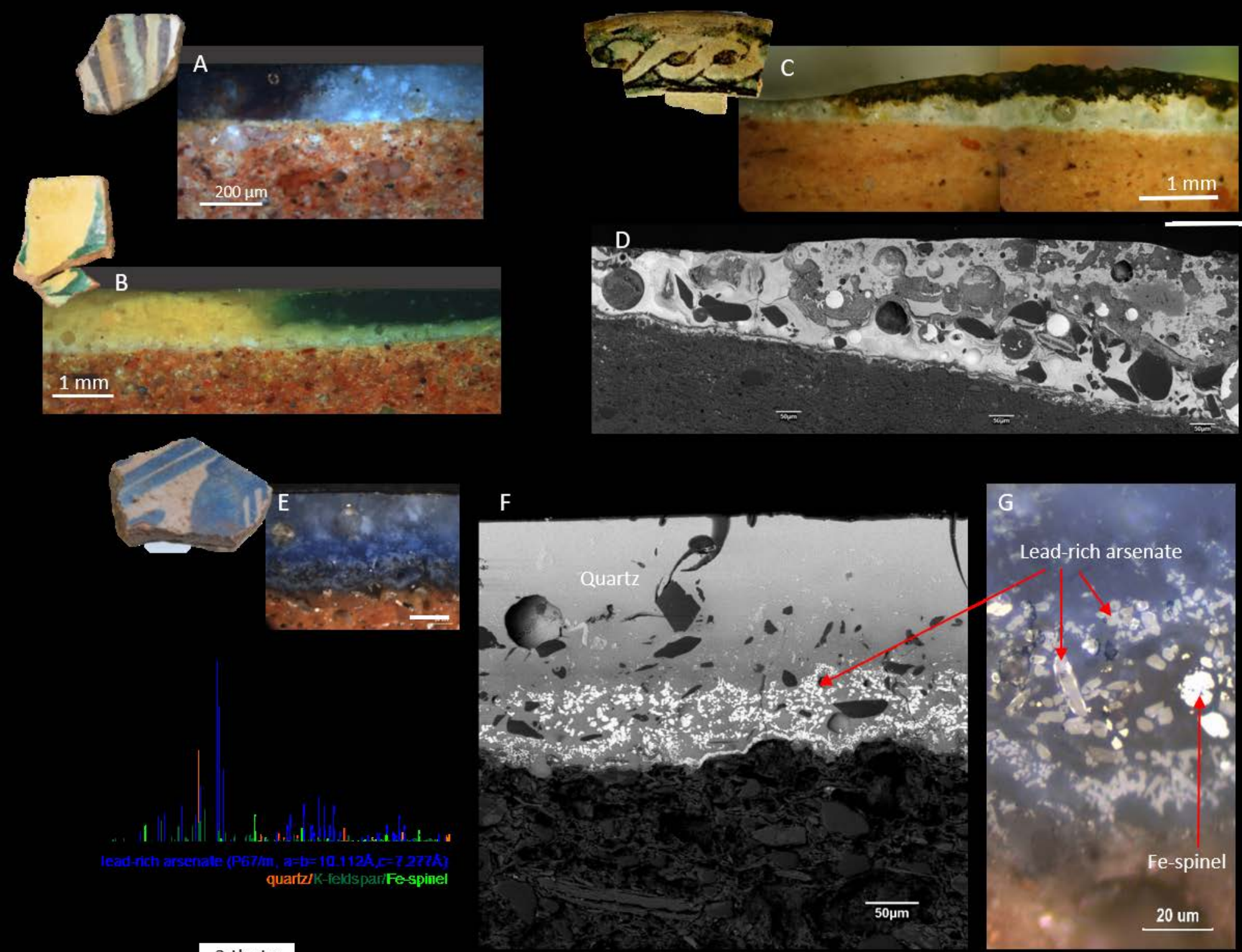



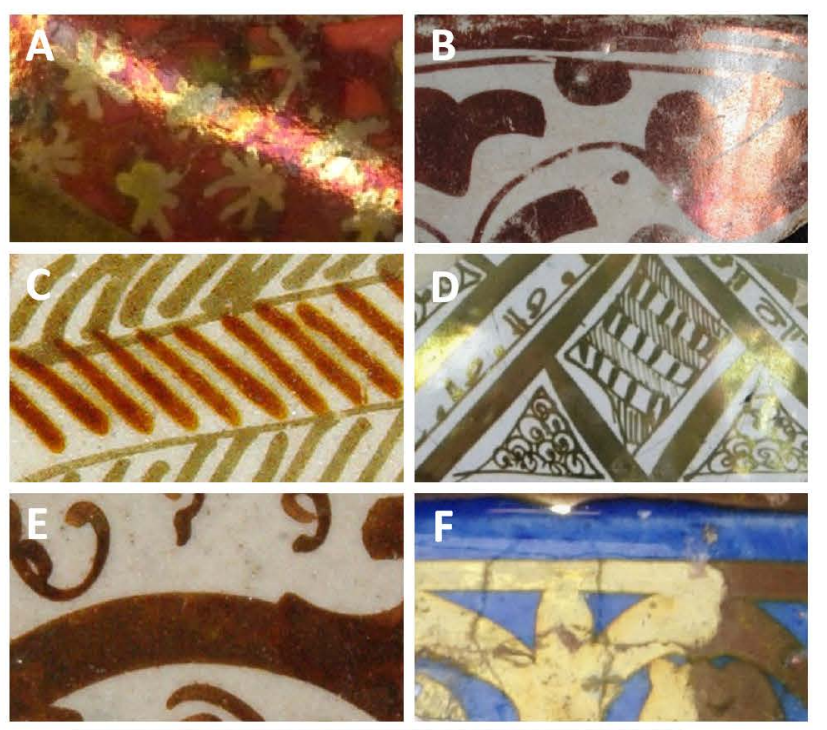

G

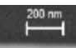

Yellow golden over red
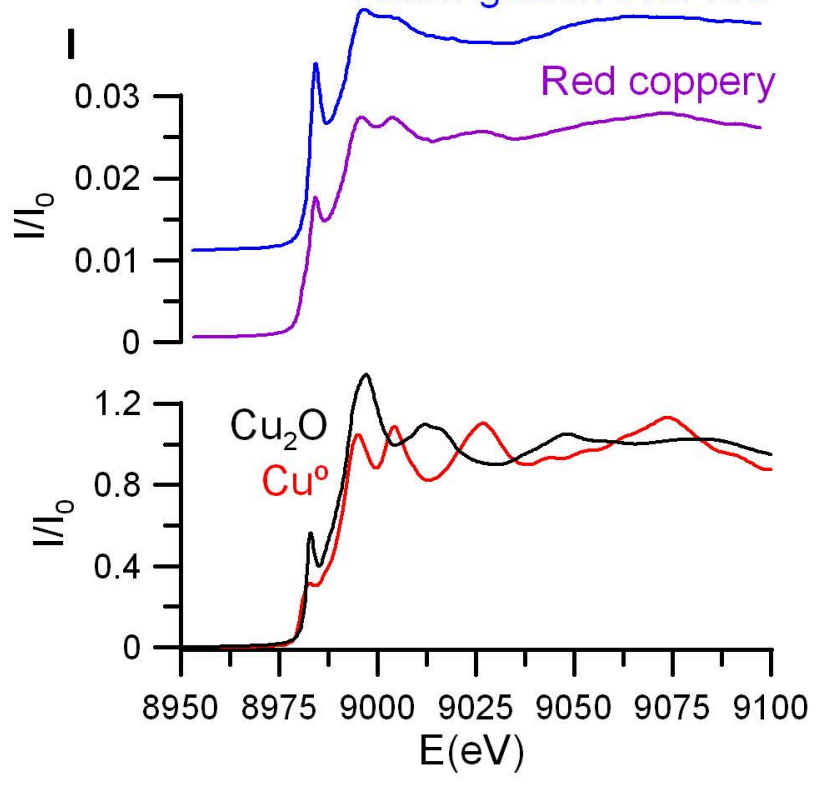

J

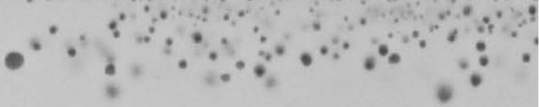

H

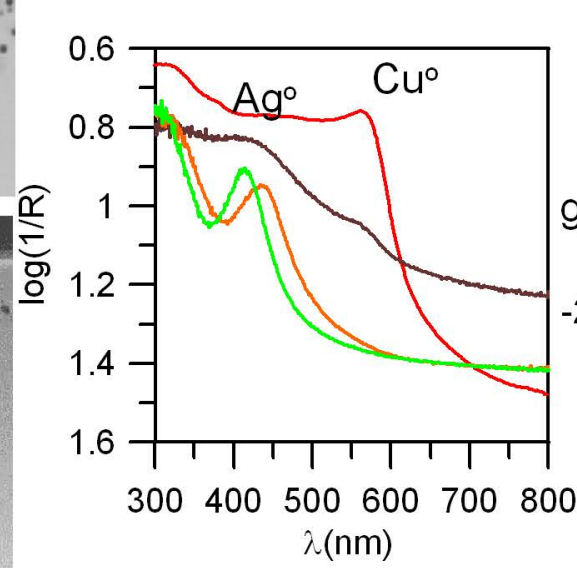

K

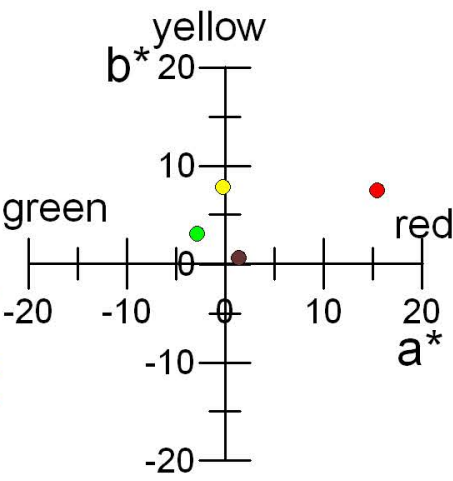

blue 
